\title{
Sinema-Mimarlık Arakesitinde Bir Mekana Dokunmak: Sine-Tasarım Atölyesi
}

\author{
Asu Beşgen* \\ Şölen Köseoğlu**
}

\section{Özet}

Bu makale, sinema ve mimarlık disiplinlerinin felsefi bir tartışma düzleminde bir arada ele alınmalarının sunabileceği potansiyellerin, bir atölye deneyimi üzerinden örneklenmesini içerir. Atölyeler, geleneksel eğitim müfredatı dışında sağladıkları esneklik ve deneysel ortam ile yeni yaklaşımların özgür bir çerçevede deneyimlenmelerine imkan sunarlar. Makaleye konu olan Sine-Tasarım Atölyesi, Yıldız Teknik Üniversitesi bünyesinde gerçekleştirilen "Mimari Tasarım Eğitimi: Bütünleşme 2" konulu Ulusal Sempozyum kapsamında lisans düzeyindeki öğrenicilerle gerçekleştirilmiştir ve benzer atölyeler için bir yöntem önerisi olmasının yanı sıra, yeni bir düşünme biçiminin örneğidir.

Atölye kapsamında öğreniciler, sinema-mimarlık ilişkisi hakkında tarihsel bir perspektifle tartışmalar yürütmüş, ardından Christopher Nolan'ın "Inception" filmini izlemişlerdir. Filmde mekan kullanımı aracılığıyla gündeme getirilen kavramlan tespit etmiş, bu sunuş biçiminden yola çıkarak mekan kavramın yeniden tanımlamışlardır. Son adımda ise, kendi özgün mekan tanımların örnekleyen iki ve üç boyutlu anlatımlarla tasarımlarmı gerçekleştirmişlerdir. Atölye sonucunda, sinemanın mimarlık eğitiminin bir parçası olarak soyut düşünme becerisi kazandırmada başarıyla kullanılabilmesinin mümkün olduğu görülmüştür. Bu türden interdisipliner çalışmalar iki alana da katkı sağlarken, her konuyu tekil birimler olarak değil, büyük bir sistemin parçaları olarak ele alan bir düşünce sistemini önermeleri açısından önemlidirler.

Anahtar Kelimeler: Sinema, Mimarlı, Mekan, Tasarım, Atölye, Eğitim.

ORCID ID : 0000-0002-9692-6224

E-mail : abesgen@gmail.com, solen.koseoglu@gmail.com

DOI: 10.31122 / sinefilozofi.516445 


\title{
Experiencing Space in between Cinema and Architecture: Cine-Design Workshop
}

\author{
Asu Beşgen* \\ Şölen Köseoğlu**
}

\begin{abstract}
This paper includes an exemplification of the potentials of the combination of two disciplines, cinema and architecture in a philosophical discussion base through a workshop experience. The workshops, providing flexibility and an experimental environment outside the traditional education curriculum, offer an opportunity to experience new approaches in a free framework. Sine-Design Workshop, which is the subject of the article, has been carried out with undergraduate students within the frame of the National Symposium on "Architectural Design Education: Integration 2" organized by Yalduz Technical University and is an example of a new way of thinking as well as being a method proposal for similar workshops.

Within the scope of this workshop, the students discussed the cinema-architecture duo with a historical perspective, followed by a screening of Christopher Nolan's "Inception". They identified the concepts raised through the use of space in this film and redefined the concept of space based on this representment. In the last step, they carried out their designs with two and three-dimensional expressions that exemplify their own specific spatial definitions. At the end of the workshop, it has been seen that it is possible to use the cinema successfully to gain abstract thinking skills as a part of architectural education. While such interdisciplinary studies contribute to both areas, they are important in terms of proposing a system of thought that treats each subject as a part of a larger system, not as individual units.
\end{abstract}

Keywords: Cinema, Architecture, Space, Design, Workshop, Education.

ORCID ID : 0000-0002-9692-6224

E-mail : abesgen@gmail.com, solen.koseoglu@gmail.com

DOI: 10.31122/sinefilozofi.516445

Recieved - Geliş Tarihi: 22.01.2019

Accepted - Kabul Tarihi: 30.03.2019 


\section{Giriş}

"Mekan hiçbir zaman boş değildir; her zaman bir anlam içerir...",

Henri Lefebvre, 2014

Tarih boyunca birçok mimar ve teorisyen tarafından yapılmış olan mimarlık tanımları incelendiğinde, mimarlığın farklı disiplinleri içeren, birçok değişken ve bileşeni içinde barındıran dinamik bir özellik taşıdığı görülmektedir.

Sinema, yapısı ve bünyesinde barındırdığı anlamsal ve teknik bileşenler gereği, mimarlık ile ilişki içinde olan birçok disiplinden sadece biridir, ancak sinema, diğer tüm sanat dallarını bünyesinde barındırmasına ek olarak hareket, zaman ve mekan boyutlarını içermesi sebebiyle mimarlıkla kurduğu ortaklık açısından diğer disiplinlerden ayrışır.

Sinemanın icadıyla başlayan sinema mimarlık ilişkisine bakıldığında, iki sanat dalının birbirinden etkilendiği açıktır. Bu etkileşim, sadece sinemanın mimarlığa etkisi şeklinde olmayıp, mimarlığın sinema tarafından kullanılmasını, doğal bir sonuç olarak da mimarlığın farklı ölçeklerde sinemadan kendine geri besleme sağlamasını beraberinde getirmiştir. Bu nedenle yapılan her filmin gerek görsel, gerek düşünsel olarak mimarlığa katkı sağlayacak bilgiyi içinde barındırdığı ve mekanın hem tasarlanması hem de algılanması konusunda bir tartışma zemini oluşturduğu söylenebilir. Tasarım yöntemleri ve mekan algısı açısından örtüşen bu iki alanın interdisipliner olarak tartışılması, mekanı, sinemanın tanımladığı sanal gerçeklikler üzerinden algılamaya alışkın bir kuşağa ait olan tasarım öğrenicilerine, mimari mekana yaklaşımları açısından katkılar sağlamaktadır. Mekanın tasarlanması, temsiliyet araçları ile yeniden üretilmesi ve ifadesi bağlamında sinema ile yakın ilişki kurulması önemlidir.

Sinema ve mimarlık disiplinleri arasındaki bu eşsiz ortaklık birçok alanda etkileşime sebep olmaktadır. Bu çalışma, bu etkileşimlerin mimarlık eğitimine sunabilecekleri potansiyel katkıların sınanmasını konu edinir. Bunu yaparken de araç olarak kendisine deneysel bir platform olan atölye ortamını seçer. Üniversitelerin yerleşik eğitim programlarının aksine atölyeler, planlama ve yöntem açısından oldukça esnek bir yapıda kurgulanabilir ve böylelikle alışılageldik eğitim programlarının sunamadığı fırsatlar sunarlar.

Eğitim sistemleri planlanırken farklı disiplinlerin bir arada ele alınabilmesinin önemini Kreber; "Üniversite ve Disiplinleri: Disiplin Sinırlarının Ötesinde Öğretme ve Öğrenme" (University and its Disciplines: Teaching and Learning Within and Beyond Disciplinary Boundaries) adlı kitabında şöyle ifade etmiştir: "Hızlı bir değişimin, karmaşıklığın ve belirsizliğin şekillendirdiği günümüz dünyasında, problemler tekil konular olarak değil, disiplinler-ötesi bağlamların parçaları olarak ortaya çıkmaktadır; bu nedenle, öğrenme çıktıları belli bir alana özgü bilgi ve becerilerin ötesine geçmelidir." (Kreber'dan aktaran ve çeviren Yorgancıŏ̆lu, 2011). Mimarlık eğitimi planlanırken de diğer sanat dalları dahil edildiği oranda öğrenicilerin disiplinlerin sınırlarını aşan bir özgür düşünme becerisi kazanacağı düşünülmektedir.

Pallasmaa'ya göre mimarlık disiplini, 1970'lerin sonlarından bu yana başka sanat dallarıyla ilişki içerisindedir. Modern gibi gözüken profesyonel uygulamaları ile taşlaşmış mimarlık paradigmasını yıkmak için mimarlıkta, resimden ve heykelden olduğu kadar 
edebiyattan ve müzikten de esinlenilmektedir. Mimarlık okullarında ve profesyonel uygulama alanlarında mimari projeler, Vermeer'in düzensel yapısından Kübist resimlere, Bach'ın müziğinden Meredith Monk'a, Heraclitus'un edebi bölümlerinden Herman Melville'in Moby Dick'ine ve James Joyce'un Finnegans Wake'ine kadar hepsinin çözümlemesi doğrultusunda üretilmektedir. Tüm bunlarla birlikte, mimarlığın kuramsal temellerine de beklenmedik bir ilgi başlamaktadır. Çeşitli alanlarda yapılan bilimsel araştırmalar, kuramsal yaklaşımlar, profesyonel çalışmalarda da mimarlık kendini göstermektedir, (Pallasmaa, 2008).

Bu yaklaşımla çalışma, Karadeniz Teknik Üniversitesi, Mimarlık Bölümü, Lisans ve Lisansüstü Programları kapsamında gerçekleştirilen “Sinema ve Mimarlık" dersinin yöntemsel olarak eleştirel bir bakış açısıyla yeniden ele alınmasına olanak tanıyan bir atölye deneyimini paylaşmayı amaçlamaktadır. Atölye, Yıldız Teknik Üniversitesi tarafından 20-21 Ekim 2011 tarihlerinde düzenlenen "Mimari Tasarım Eğitimi: Bütünleşme 2" konulu Ulusal Sempozyum kapsamında lisans düzeyindeki öğrenicilere yapılan açık çağrıyla gerçekleştirilmiştir. Sempozyum öncesinde yapılan açık çağrı sonucu, ulusal ölçekte, lisans seviyesinde 18 öğrenici atölyeye katılmıştır. Atölye iki gün sürmüştür ve sonuç ürünleri sempozyum katılımcılarıyla bir sergi ve sunum aracılığıyla paylaşılmıştır.

Atölye kurgusu; öğrenicilere sinema-mimarlık ilişkisi hakkında anlatımların tarihsel bir perspektiften aktarılması, öğrenicilerin izlenen filmle ilgili tartışmalar üzerinden mekana dair soyut kavramlar üretmeleri, kendi mekan tanımlarını yaparak tanımları mekan tasarımlarına dönüştürmeleri biçiminde gerçekleşmiştir. Çalışmanın üst amacı olan; öğrenicilere sanatla yaşamı uzlaştıran öğretinin kazandırılması aracılığıyla soyut düşünme becerisinin geliştirilmesi hedeflenmiştir. Bu bağlamda, düşünsel bir temeli olan tasarım üretiminin kavramlar üzerinden kurgulanması, tasarım fikirlerinin sinema ve mimarlıkta mekan kurgusu aracılığıyla geliştirilmesi, bir film üzerinden yeni ve özgün mekan tasarımlarının yapılması, öğrenicilerin kendilerini geleneksel eğitim ortamı dışında özgürce ifade edebilmelerinin atölye aracılığıyla desteklenmesi çalışmanın alt hedefleri arasındadır.

Atölyenin yer aldığı sempozyum, "kuram, kavram ve pratiğe dayalı yaklaşımların irdelenmesi" amacıyla ve "mimarlık alanına, ulusal-uluslararası akreditasyon süreçlerine ve Türkiye Yükseköğretim Yeterlilikler Çerçevesi'ne yol gösterici katkılar sağlayacağı öngörüsüyle" mimari tasarım eğitiminde stüdyo yaklaşımları ve deneyimlerini, kuramsal ve uygulamalı dersleri, bilgi üretme, bilgi edinme ve öğrenme sürecini, mimarlık ve ilgili disiplinlerin birlikteliğini, son olarak da enformel yaklaşımları tartışmaya açmak üzere kurgulanmıştır, (“Mimari Tasarım Eğitimi: Bütünleşme”, 2011).

Tam da bu kapsamda bir tartışma yaratmak üzere atölyenin ve bu çalışmanın aşağıdaki soruların araştırılmasına olanak sağlayacağı düşünülmüştür:

- Mimari tasarım eğitiminde disiplinler arası yaklaşımlar nasıl kurgulanabilir?

- Genel olarak sanat, özel olarak da sinema öğrenicilerin hayatına katkılar sunabilir mi?

- Genel olarak sanat ve mimarlık, özel olarak da sinema ve mimarlık soyut düşünme temelinde bir araya getirilebilir mi?

- $\quad$ Sinema, mimari tasarım eğitimine katkılar sunabilir mi?

- $\quad$ Bir film, bir sahne, bir düşünce mekan tasarımına kaynaklık edebilir mi? 
- $\quad$ Bir filmi veya bir mekanı oluşturan düşünce bu iki disiplinin sınırlarını eritebilir mi?

- $\quad$ Filmler aracılığılyla soyut düşünme becerisi geliştirilebilir mi?

- $\quad$ Filmler aracılığıyla kavramlar üretmek veya onları yeniden tanımlamak mümkün müdür?

- Üretilen ve tanımlanan kavramlar aracılığıyla tasarlama etkinliği gerçekleştirilebilir mi?

- $\quad$ Üniversitelerin ve yerleşik eğitim programların kalıplarını aşan bir öğrenme ortamı mümkün müdür?

- Alışılagelmiş eğitim ortamlarının yaratıcılık üzerindeki olumsuz etkileri nelerdir, budurumun alternatifi olası hale nasıl getirilebilir?

- $\quad$ Özgür öğrenme ortamını sağlamak mümkün müdür?

- $\quad$ Özgür öğrenme ortamı atölyeler aracılığıyla gerçekleştirilebilir mi?

$\mathrm{Bu}$ çalışma için metin, beş ana bölüm içerecek şekilde kurgulanmıştır. İlk bölümde, sinema ve mimarlık alanlarının etkileşim biçimleri tarihsel perspektifte açıklanmış; iki alanın ortaklıkları ve bu alandaki literatür sinema tarihinden seçilen filmlerle örneklenerek kısaca özetlenmiştir. İkinci bölüm, Türkiye'de mimarlık eğitiminde sinemanın yerini konu edinmiştir. İlk iki bölüm ardından, üçüncü bölüm, yazının konusu olan atölye yönteminin tercih edilme sebebini ortaya koymayı amaçlamıştır; bu bağlamda, çalışmanın kalbidir; SineTasarım atölyesini, kurgulanma aşamasından sonuç ürünlerine kadar, detaylarıyla açıklar. Son bölüm ise sonuçlar ve önerileri içermektedir.

\section{Sinema ve Mimarlık Üzerine...}

"Filmler, mimarın en cesur rüyalarının sadık çevirmeni olacaktır...",

Sanat etkinliği en geniş anlamıyla benliğin kişiliğe dönüşmesi eylemi olup dışımızdaki dünyalara duyulan ilgi ve bilinmeyenlerin çekiciliği de bu eylemimizi besleyen ana damarlardır, (Bozkurt, 1995). Var olanla olmayan arasında bir yerlerde bulunan sanatsal süreç içinde insan, eli, yüreği ve kafası ile birlikte yol alır; sezgi, duygu, imgelem ve duyu organlarını birlikte çalıştırır. Sanat her şeyden önce insanın var olana bir karşı çıkışı, varlığa bir meydan okumasıdır; insanın gerçekliği aşması, düşle gerçek arasında kurulan bir köprü yaratmasıdır. Kısaca sanat, insanın kendini tanımasının, dönüştürmesinin ve yaratmasının bir dışavurumu ya da bir serüvenidir. Bu serüven sonunda insanın, başkaları aracılığıyla kendini tanıdığı, varlığını kanıtladığı, kendini aşma çabası içinde kendi bilincine vardığı gözlenir.

Mimarlık ise en basit tanımıyla "yapı yapma sanat ve bilimi"dir, (Soygeniş, 2006). Bu bağlamda mimarlık, ortaya koyduğu ürünlerin etrafında kurulmuştur. Mimarlık tarihine 
bu ürünlerin niteliklerinin değişimi üzerinden bakıldığında, mekan kavramı "mimarlığın baş aktörü" (Zevi, Barry, ve Gendel, 1957) olarak görülür ve mimarlık tarihi de bir "mekan kavramlarısilsilesi" ne (Dostoğlu, 1981) dönüşür. Bu anlamda, mimari yapı oluşturma sürecinde tanımlamalar, arayışlar ve yöntemler zaman içinde değişse bile kilit kavram olan mekana verilen önemin değişmediği açıktır. Tarih boyunca birçok mimar ve teorisyen tarafından yapılmış olan mimarlık tanımları incelendiğinde mimarlığın farklı disiplinleri içeren, birçok değişken ve bileşeni içinde barındıran dinamik bir özellik taşıdığı görülmektedir.

Sinemanın icadıyla başlayan sinema mimarlık ilişkisi, günümüze kadar farklı şekillerde gelişerek sıkı bir bağa dönüşmüştür. İki sanat dalı da birbirlerinden etkilenmiş ve birbirlerini kullanmışlardır. Bu etkileşim, sadece sinemanın mimarlığa etkisi şeklinde olmayıp, iki yönlü olarak gelişmiş ve sinemanın başlangıcından günümüze kadar farklı şekillerde kendini göstermiştir. Mimarlığın yoğun bir biçimde sinema tarafından kullanımı, doğal bir sonuç olarak mimarlığın farklı boyutlarda geri besleme sağlamasını beraberinde getirmiştir. Bu nedenle yapılan her filmin gerek görsel, gerek düşünsel olarak mimarlığa katkı sağlayacak bilgiyi içinde barındırdığı ve mekanın hem tasarlanması hem de algılanması konusunda tartışma zemini oluşturduğu söylenebilir.

Baysan Serim, (2014) ise mimarlık ve sinema ilişkisini bir ittifak olarak nitelendirir ve bu ittifakın "soy kütüğü" üzerinde yaptığı araştırmasında, ilk insanların mağara duvarlarına çizdiği "hareketli resimler"i köken veya bir eşik olarak değerlendirebilmeyi sorgulayıp ekler: "Hem sinema hem de mimarlık, düşünsel, bilimsel, estetik, toplumsal, teknolojik ve kurumsal ilişkilerin oluşturduğu, indirgenmesi imkansız heterojen bir sistemin etkisi olarak mümkündür"... "Hem mimaride hem de sinemada her imge, insanın düşünmesine açılan 'planlama, tefekkür, problem çözme, hatırlama, hayal kurma, akıl yürütme, mecazlarla, metaforlarla, figürlerle ifade etme, muhakeme, tahayyül etme' gibi araçlarla yapılanmıştır", (Baysan Serim, 2014 ve Frampton 2013).

Sinema ile mimarlık arasındaki etkileşimlerden ilk akla gelenler ikisinin de görsel ve düşünsel yanlarıdır. Tanyeli'ye (2001) göre ise üç tip ilişki/etkileşim söz konusudur: Birincisi sinemanın "inşa edilmemiş" ve gerçeklik düzleminde var olmayan "bir sanal mimarlık alanı" tanımlamasıdır. İkinci ilişki sinemanın "gerçek" mimari mekanları, kendi sanal evreninde yeniden üretmesidir. Üçüncü ve son ilişki ise sinemanın, kendi olay kurgusu içinde, "bir kişilik olarak mimarı ve mimarlık etkinliğini" konu almasıdır, (Tanyeli, 2001). Bu üç etkileşim türü, aşağıdaki filmlerle örneklenebilir, (Bkz. Tablo 1):

Tablo 1. Tanyeli'nin Üçlü Etkileşim Sisteminin Filmler Üzerinden Örneklenmesi

\begin{tabular}{ll}
\hline & - 2001: A Space Odyssey (1968) \\
& - Truman Show (1998) \\
Sanal Mimarlı & - The Dark Knight (2008) \\
\hline & - Camille Claudel (1988) \\
- Frida (2002) \\
- Modigliani (2004) \\
\hline Merçeğin Yeniden Üretimi & - Fountainhead (1949) \\
\hline İçermesi & - The Belly of an Architect (1987) \\
&
\end{tabular}


Ne var ki sinema ve mimarlık arasındaki etkileşim türleri sadece bu üçlü sistemle kategorize edilemeyecek kadar çoktur, (İnce, 2007). Çalışma kapsamında, iki disiplin arasındaki etkileşim türlerinin tartışılması aşağıda yer aldığı gibidir, (Bkz. Tablo 2):

Gerek sinema gerekse mimarlık, üretim süreçlerinde benzer aşamalardan geçer; uygulama aşamasına kadar benzer yöntemler kullanırlar. Her iki sanat dalı da zihinde başlar, kağıda aktarılır, parçalar oluşturulur ve bütün elde edilene dek değişiklik geçiren parçalar sonuçta birleştirilerek ürün ortaya çıkarılır ki bunların çoğunun mimarlığın da kullandığı terimler olduğu görülür. Sinemanın kullandığı görsel dile bakıldığında; "çerçeve”, , kamera açıları", "bakış açısı", "perspektif”, "çekim ölçekleri”, "1şık-renk" ve "zaman” ile karşılaşılır. Sinemada kullanılan"montaj", "senaryo", "çerçeveleme" gibibirçoksinemayaait terminolojinin gün geçtikçe daha çok mimar tarafından kullanıldığı görülmektedir. Le Corbusier, "çerçeveleme"; Jean Nouvel, "montaj" ve "çerçeveleme"; Rem Koolhaas, "senaryo"; Bernard Tschumi, "senaryo", "montaj" ve "çerçeveleme", "üst üste bindirme (superimposition)", "yan yana koyma (juxtaposition)", “sekans", "kesme”, "hareket”, “olay", "program”, mimarların tasarımlarını anlatırken kullandığı sözcüklerden sadece bazılarıdır, (Beşışık, 2013). Sonuç olarak, sinema ve mimarlığın kullandığ1 görsellik, hareket, kompozisyon, 1şık, mekan, kurgu, ses ve sayılabilecek daha pek çok ortak terminoloji ve bu terminolojinin gösterdiği yöntemsel benzerlikler, ortaya çıkarılan ürünlerde, iki sanatın birbirleriyle etkileşime girmesini ve bă̆ kurmasını kaçınılmaz kılmaktadır.

Ayrıca sinema, var olmayan bir mimariyi yaratabilmek için kullanılabilen bir ortam olmakla birlikte, mevcut mimarinin farklı kullanıcılar ya da farklı kullanım amaçları için kullanımını gözler önüne serebilecek ve yapıların, gelecek nesiller ya da durumlar karşısında ne şekillerde yeniden kullanılabileceğini gösterebilecek bir ortam olarak da görülmelidir. Mevcut mimariyi oluşturduğu yaşam biçimiyle sorgulayabilecek, onun gelecekte meydana getirebileceği sorunları ortaya çıkarabilecek veya yenilikçi mimarilerin ütopik filmler ile ne yöne doğru gittiğinin ya da gidebileceğinin üzerine tartışma ortamı yaratabilecek bir ortam olarak sinema, mimarlara yeni bir platform sunmaktadır. Örneğin; Jack Tati, Playtime (1967) filminde modernizmi eleştirmiştir, filmdeki taşlamanın aslında yaşanılan yer hakkında değil, onun nasıl yaşandığı hakkında olduğudur.

Sinemanın hem yapılan film okumalarıyla, mekanın algılanması ve mekan anlam ilişkisinin kavranması açısından hem de mekan yaratma teknikleri açısından kullanılan elemanların ve yöntemlerin kavranması açısından mimarlar için eğitsel bir yöne sahip olduğu söylenebilir. Buna ek olarak sinemanın, toplumun mimarlığa ve mekana olan farkındalığını arttırma ve mekanın daha bilinçli kullanımı adına bilinçlendirici bir rolünün olduğu da görülmektedir. Bir şehir kuş bakışı görülebilir, tüm şehir tek karede algılanabilir, ya da tam tersi bir karıncanın gözünden küçük bir oda, bir şehir edasıyla yeniden deneyimlenebilir. Bu noktada, insanoğlunun algılayamayacağı bakış açılarından tamamen farklı bir ölçekte mekan algılanmış olur. Filmin öğrenim aşamasında olan genç mimarlara, sinemadaki kent, mekan, 1şık, zaman, hareket ve ölçek gibi kavramların aktarılmasının, mekana ait özelliklerin görsel olarak zihinde canlandırılması açısından büyük yarar sağlayacağı açıktır. Önemli yönetmen, yapımcı, sanat yönetmeni ya da set tasarımclarına bakıldığında, birçoğunun geçmişlerinde mimari üzerine çalışma yaptığ 1 ya da eğitim gördüğü görülmektedir. Bu bize, mimarlık eğitimi geçmişinin, değişik dönem özelliklerini bilmenin fonksiyonel, kabul edilebilir setler yapmada kolaylık sağladığını göstermektedir. 
Sinema ve mimarlık ilişkisinde yer alan diğer bir etkileşimin akımlar üzerinden gerçekleştiği söylenebilir. Sinemanın giderek önem kazandığı ve güçlendiği dönemler, ekspresyonizm ve modernizm akımlarıyla çakışmaktadır ve mimarlık sinema etkileşiminin bağlarının bu dönemde kuvvetlendiği görülmektedir.

Ayrıca sinema ve mimarlık, birer tarihi kanıt, belge olarak dikkat çekmektedir. Bu dokümanter nitelik, her iki sanata karşılıklı bir etkileşim alanı açmıştır. Her yapı yapıldığı tarihi yansıtan bir ayna gibidir; dönemin sosyal, kültürel, inanış özelliklerinden, bölgenin coğrafi ve iklimsel koşullarına birçok özelliği içinde barındırır. Bu özellikler, sinema tarafından olmazsa olmaz özellikler olarak ortaya çıkar ve filmlerde mimarinin verdiği bu bilgilerin kullanımını zorunlu kılar. Yapılan filmin inandırıcılı̆̆ı; kullanılan mimariye, kıyafetlere, müziklere, mekanı kullanan ve şekillendiren insan davranışlarına göre başarılı ya da başarısız olur. Housing Problems (1935) adlı film kenar mahallelerdeki mevcut durumu yerinde görüntülemiş, bu dönemin mimarisini ve konut problemlerini belirlemiş, When We Built Again (1942), A City Reborn (1945), Proud City (1945), Piyanist (2002) gibi filmlerde de savaş sonrasında şehirlerin nasıl olacağına dair bilgiler verilmeye çalışılmıştır.

Tüm bunlar, sinema ve mimarlığın ürünlerini oluştururken bazı ortak elemanlara ihtiyaç duyduğunu ve/veya bu elemanlardan etkilendiğini ortaya koymaktadır. Işık, model, ses, doğa, insan gibi elemanlar, bunlardan sadece birkaçıdır. İlgili elemanların kullanış amaçları ve şekilleri benzerlikler göstermekle birlikte zaman zaman farklılıklar da göstermektedir. Örneğin sinema, insanı hem bir oyuncu olarak kullanır hem de ona hizmet eder. Mimarlık da insana hizmet eder, aynı zamanda insana hizmet ettiği için insanı bir ölçüt olarak kullanır.

Tablo 2. Sinema-Mimarlık Etkileşim Sisteminin Filmler Üzerinden Örneklenmesi

\begin{tabular}{|c|c|}
\hline Yöntemsel-Terminolojik Etkileşim & $\begin{array}{l}\text { - Metropolis (1927) } \\
\text { - Villa Savoye'nin Mimarisi (1929) } \\
\text { - Roma, Açık Şehir (1945) }\end{array}$ \\
\hline $\begin{array}{l}\text { Sinemanın Mimarlığa Deneysel Bir } \\
\text { Ortam Sunması }\end{array}$ & $\begin{array}{l}\text { - Frankenstein (1931) } \\
\text { - Lost Horizon (1937) } \\
\text { - Mon Oncle (1958) }\end{array}$ \\
\hline Eğitsel Etkileşim & $\begin{array}{l}\text { - Play Time (1967) } \\
\text { - Germinal (1993) } \\
\text { - Microcosmos (1996) }\end{array}$ \\
\hline Akımlar & $\begin{array}{l}\text { - Doktor Caligari'nin Muayenehanesi (1920) } \\
\text { - Metropolis (1926) } \\
\text { - A City Reborn (1945) }\end{array}$ \\
\hline $\begin{array}{l}\text { Film ve Mimarinin Belge Olma } \\
\text { Nitelikleri }\end{array}$ & $\begin{array}{l}\text { - Housing Problems (1935) } \\
\text { - When We Built Again (1942) } \\
\text { - A Diary for Timothy (1945) }\end{array}$ \\
\hline Ortak Eleman Kullanımı & $\begin{array}{l}\text { - Kamerali Adam (1929) } \\
\text { - Hiroşima Sevgilim (1959) } \\
\text { - Casino (1995) }\end{array}$ \\
\hline
\end{tabular}


Ve mekan... Çalışma kapsamında, sinema ve mimarlık ara kesitinde, her iki bilim ve sanat dalının en önemli ortak kullanımıdır, ancak mekan sinemada ve diğer sanat dallarında bir araçken mimaride sanat mekanı yaratmak için kullanılır. Bu özellik, sinematik mekanı mimari mekandan ayıran önemli özelliklerden biridir. Sinemada amaç, mekan tanımlamak ya da yaratmak değildir. Mekan, amaca ulaşmak için kullanılan bir araç niteliğindedir. Mekan, senaryo, müzik, ışık ve aktörler gibi kaçınılmaz elemanlar biridir. Sinemada mekanın oluşturulması, kimi zaman mevcut mekan kullanımı ile kimi zamansa kurgusal mekan yaratılması ile gerçekleşir. Mekan; bazen fon, bazen tamamlayıcı, bazen de bir başrol oyuncusu gibi şekilden şekle girer, (Bkz. Tablo 3).

Tablo 3. Sinemada Mekan Kullanımının Filmler Üzerinden Örneklenmesi

\begin{tabular}{cl}
\hline Fon, Tamamlayıcı ve Başrol & - Berlin: Die Sinfonie der Grosstadt (1927) \\
Oyuncusu olarak & - Gülün Adı (1986) \\
Mevcut Mekan Kullanımı & - Cinema Paradiso (1998) \\
\hline Fon, Tamamlayıcı ve Başrol & - Blade Runner (1982) \\
Oyuncusu olarak & - Beşinci Element (1997) \\
Kurgusal Mekan Yaratılması & - Matrix (1999)
\end{tabular}

\title{
Sinema ve Mimari Tasarım Eğitimi Üzerine...
}

\begin{abstract}
"Sinemanın şürselleştirilmiş mimarisi üzerinde çalışmanın, mimarlara, hayatın ve mimarların kendi sanat formlarının sembolik ölçülerini yeniden keşfetmeleri için yardımcı olacaktır...

Hem mimarlık hem de sinema yaşanan mekanıaçıklar...

İki sanat dalı da var olan mekanın özünü ve boyutlarını tanımlar; ikisi de hayat durumlarmın deneysel sahnelerini yaratır...",

Juhani Pallasmaa, 2001
\end{abstract}

Eğitim etkinliği bireyin davranışında kasıtlı olarak istenilen yönde bir değişme meydana getirme sürecidir ve bu süreçte bireyin kendi yaşantıları esastır (Ertürk, 1997). Bir mimari mekanı öğrenicilere anlatırken, öğreniciler tarafından bilindik ve tanınan araçlara başvurulması, yararcı bir yöntem olarak karşımıza çıkmaktadır. Bir tasarım kapsamında, tasarımcının zihni, zihnin iki boyutlu temsili ve üçüncü boyutta dışavurumu aşamalarında izlenen süreci, sinema ve mimarlık araçları kullanarak yorumlamak, mimari tasarım süreci ve mekan ilişkisini daha anlaşılır kılmaktadır.

Bugün Türkiye ve KKTC'deki 100'ün üzerindeki üniversitede mimarlık eğitimi verilmektedir, (YÖK, 2019). Tespit edilebildiği kadarıyla geçtiğimiz yıllarda mimarlık eğitimi verilen en az 20 fakültede sinema ve mimarlık ilişkisini tartışan, çeşitli isimlerde lisans düzeyinde 1 veya 2 sömestr süren seçmeli dersler açılmıştır, (Bkz. Tablo 4). Bu derslerin ilk defa ortaya çıkmaya başladığı 2000'li yılların başında İstanbul'da sinema ve tasarım ilişkisini konu 
edinen ulusal ve uluslararası toplantılar yapılmış (Design and Cinema: Design in Wonderland, 2003 ve Design and Cinema: Form Follows Film, 2005), bu alanda yayınlar üretilmiştir. 1990'l1 yılların sonlarından itibaren de ilk defa sinema ve tasarım ilişkisine odaklanan yüksek lisans ve doktora tez çalışmaları yapılmış, gitgide artan oranda konunun tartışılma zemini akademik alanda genişlemiştir. Böylelikle çok daha erken yıllarda üretilen yabancı literatürün peşi sıra ulusal çalışmalarla da konu görünürlük kazanmıştır.

Tablo 4. Türkiye'de Sinema-Mimarlık Dersinin Verildiği Üniversiteler ve Ders İsimleri

\begin{tabular}{ll}
\hline Üniversite & Seçmeli Ders Adı \\
\hline Anadolu Üniversitesi & Sinema ve Tasarım \\
\hline Balıkesir Üniversitesi & Sinema ve Mimarlık \\
\hline Dokuz Eylül Üniversitesi & Sinema ve Mimarlık \\
\hline Işık Üniversitesi & Mekan ve Sinema \\
\hline İstanbul Bilgi Üniversitesi & Video ve Mimarlı \\
\hline İstanbul Kültür Üniversitesi & Sinema' da Modernlik ve Mimarlık (I ve II) \\
\hline İstanbul Medipol Üniversitesi & Sinema ve Tasarım \\
\hline İstanbul Teknik Üniversitesi & Architecture, Cities and Cinema (Mimarlık, Kentler ve \\
\hline İzmir Ekonomi Üniversitesi & Sinema) \\
\hline İzmir Yüksek Teknoloji Üniversitesi & Architecture in Films (Sinemada Mimarlık) \\
\hline Karadeniz Teknik Üniversitesi & Cinema and Design \\
\hline Maltepe Üniversitesi & Sinema ve Mimarlık Grameri \\
\hline Mimar Sinan Güzel Sanatlar Üniversitesi & Sinemasal Mekanın Tasarım Kriterleri \\
\hline Nişantaşı Üniversitesi & Mimari Tasarımda Farklı Boyutlar \\
\hline Ortadoğu Teknik Üniversitesi & Sinema ve Mimarlık \\
\hline Selçuk Üniversitesi & Design and Cinema (Tasarım ve Sinema) \\
\hline TOBB Ekonomi ve Teknoloji Üniversitesi & Sinemada Mimari Okumalar \\
\hline Yaşar Üniversitesi & Mimarlık, Kent, Sinema \\
\hline Yeditepe Üniversitesi & Sinema ve Mimarlık \\
\hline Yıldız Teknik Üniversitesi & Görsel Mimarlık Okumaları \\
\hline
\end{tabular}

Bu derslerin içeriklerine bakıldığında, sinema-mimarlık etkileşimi başlığında değinilen çeşitli yaklaşımlarla, mimarlık alanına dair çıkarımlarda bulunulması amacıyla, belirli filmlerin seçildiği ve araç olarak kullanıldığı görülmektedir.

Sinema ve Mimarlık dersleri, mimarlık eğitimi içinde öğrenicilere mimari mekanın davranışla şekillenen üç boyutlu zaman-mekan boyutunu anlatmak için büyük bir fırsat olarak karşımıza çıkmaktadır. Zira mevcut eğitimde kullanılan, iki boyutlu çizimler ve üç boyutlu olmasına rağmen maddi sebeplerle insan ölçeğinde üretilemeyen maketler; öğrenicilerin mekanı üç boyutlu olarak hareket ve zaman yönleriyle kavramaları konusunda yetersiz kalmaktadır. Bu ihtiyacı karşılamak için Türkiye' nin ve dünyanın önemli mimarlık okullarında gitgide artan oranda sinemayı mimarlıkla ilişkilendiren dersler açılmaktadır. Bu gerçek Pallasmaa aracılığıyla; "Dünyadaki birçok mimarlık okulunun ilgi alanı son günlerde sinemaya kaydı. Filmler daha incelikli ve daha duyarlı bir mimarlık keşfetme amacıyla izleniyor. Ayrıca bugünün yenilikçi mimarlığının en saygın temsilcilerinden Bernard Tschumi, Rem Koolhas, 
Coop Himmelb(l)au ve Jean Nouvel de sinemanın, mimari yaklaşımdaki önemini ve anlamını kabul eden isimler olarak biliniyor. Müzik sanatı, bugüne kadar mimarlığa en yakın sanat dalı olarak görülürken, sinema mimariye müzikten daha yakın. Sinema, sadece zamansal ve mekansal yapısından dolayı değil, yaşayan bir mekanı ifade edişiyle bu konumunu kazanıyor. Mimarlık ve sinema, yaşamın çok yönlü görüntülerini oluşturmalarından, bu oluşuma aracılık etmelerinden dolayı birbirleriyle sıkı bir ilişki içerisinde yer alıyorlar. Binalar ve kentler, kültürün ve belirli bir yaşam biçiminin görüntülerini yaratıp koruyorlar. Sinema, hem yarattığı hem de içinde bulunduğu zamanın kültürel arkeolojisini ortaya çıkarıyor. Sinema da, mimarlık da var olan mekanın özünü ve boyutlarını tanımlıyor. İkisi de yaşamın içinde deneysel sahneler yaratıyor", şeklinde ifade edilmektedir, (Pallasmaa, 2008).

Lisans düzeyinde açılan derslere ek olarak Karadeniz Teknik Üniversitesi gibi bazı üniversitelerde benzer içerikli lisansüstü dersler de mevcuttur. Genel olarak "sinema ve mimarlık" konusunda üretilmiş Türkçe akademik çalışmalar da halen tezler ve makaleler biçimindedir. Bu tezler sinema ve mimarlık alanlarının interdisipliner bir biçimde karşılıklı olarak diğer alana sağlayabileceği yeni bakış açılarını araştıran, birbirini kaynak veya araç olarak kullanma yöntemlerinin denendiği, yöntemsel, terminolojik ve içerik yönünden konuya yaklaşan çalışmalardır. Bu konudaki tezlerin çokluğuna rağmen Türkçe basılı kaynak yok denecek kadar azdır. Lisansüstü düzeyindeki sinema ve mimarlık içerikli dersler, sadece Türkiye' de değil Amerika Birleşik Devletleri başta olmak üzere Batı' daki mimarlık okullarında da verilmektedir.

$\mathrm{Bu}$ çalışma kapsamında üniversitelerin yerleşik ders programlarındaki eğitim yönteminin aksine daha informel bir deneyim konu edinilmektedir. Bu tercihin sebebi bir sonraki bölümde tartışmaya açılacaktır.

\section{Sine-Tasarım Atölyesi...}

"Anlatı (öğretmenin anlatıcı oluşuyla) öğrencilerin, anlatılan şeyi mekanik olarak ezberlemelerine yol açar. Daha beteri, onlar, öğretmen tarafindan doldurulması gereken "bidonlar"a, "kaplar"a dönüştürmesidir. Öğretmen kaplarn ne kadar çok doldurursa, o kadar iyi bir öğretmendir. Kaplar ne kadar pısırnksa, doldurulmalarnna izin veriyorsa, o kadar iyi ögrencidir... Fakat son tahlilde bu (en iyi deyimle) yanlış yoldaki sistemde, yaratıcılık, dönüşüm ve bilgi yoksunluğu yüzünden "rafa kaldırllan" bizzat insanlardır. Çünkü kendileri araştırmadan, praksis olmaksızın, insanlar hakikaten insani olamazlar. Bilgi ancak ve ancak,buluş ve yeniden-buluş yoluyla, dünya içindeki, dünya ile ve birbirleriyle olan insanların sabırsız, durmak bilmeyen, sürekli, umut dolu araştırmalarıla peşinden koşmalarryla meydana gelir."

Paulo Freire, 1995

Tasarım okullarında hiyerarşisiz eğitim mümkün mü sorusuyla tohumlanan SineTasarım Atölyesi, yaratıcı düşünmenin öğretme ve öğrenme döngüsündeki önemine sıkı sıkıya bağlıdır. Bu bağlamda, otoriter ortamların, yaratıcı düşünmenin önündeki en önemli engellerden biri olduğuna inanılmaktadır. 
Fisher (1995) yaratıcı ve özgür düşünmeyi engelleyici davranış kalıplarını şöyle tanımlar: Baskıcıdır, kötümser, hata odaklı, hoşnutsuzdur, yanıtı önceden kararlaştırır, hep en iyi olduğunu sanır, tüm kararları kendi vermek ister, hükmeder, engelleyicidir, önerilere değer vermez, kendisi için alışılmış olanın dışına çıkmaz. Bu davranış kalıpları tekrarlandığında bireylerin özgüveni zedelenir, onlara bu davranışı uygulayan kişiyle kıyasla değersiz oldukları hissini aşılar. Bireylerin kendine karşı özgüveni ve saygısı, yaratıcı düşünme için gerekli olan tutumların başında gelir ve bireyin farklı olmayı göze alabilmesi, hayal gücünü kullanabilmesi, esnek bir biçimde düşünebilmesi ve düşündüklerini dile getirebilmesi için anahtar rolü üstenir, (Doğanay, 2002.)

Eğitimin temel amacı; eski kuşakların yaptıklarını tekrar eden değil, yeni şeyler yapabilme gücünde olan insanlar yetiştirmektir; bu ancak kendine sunulan her şeyi olduğu gibi kabul etmeyen, sorgulayabilen, eleştirebilen ve yeniden üretebilen beyinler geliştirebilmekle mümkün olabilir, (Piaget'ten aktaran Fisher, 1995 ve Doğanay, 2002). Buna karşın geleneksel eğitim kurumları, kanıksanmış bir "öğretmen/öğrenci çelişkisi” içinde işlev görürler. Bu çelişki aşağıdaki biçimde açıklanabilir:

- $\quad$ Öğretmen öğretir ve öğrenciler ders alır.

- $\quad$ Öğretmen her şeyi bilir, öğrenciler hiçbir şey bilmez.

• $\quad$ Öğretmen düşünür, öğrenciler hakkında düşünülür.

- $\quad$ Öğretmen konuşur, öğrenciler uslu uslu dinler.

- $\quad$ Öğretmen disipline eder, öğrenciler disipline sokulurlar.

- $\quad$ Öğretmen seçer ve seçimini uygular, öğrenciler buna uyarlar.

- Öğretmen yapar, öğrenciler öğretmenin eylemi yoluyla yapma yanılsamasindadırlar.

- $\quad$ Öğretmen müfredatı seçer ve (kendilerine danışılmayan) öğrenciler buna uyarlar.

- $\quad$ Öğretmen bilginin otoritesini, kendi mesleki otoritesiyle karıştırır ve bu otoriteyi öğrencilerinin özgürlüğünün karşıtı olarak öne sürer.

- Ö̈̆gretmen öğrenme sürecinin öznesidir, öğrenciler ise sadece nesnedirler, (Freire, 1995).

Tüm bu alışkanlıklar, eğitim ortamıyla sınırlı kalmayan sonuçları, edilgen bireyler üzerinden tüm toplumu otoriter devletlerin vatandaşları olarak tanımlayan davranış kalıplarını yeniden üretmeye ve benimsetmeye hizmet etmektedir.

Oysa özgürlükçü öğrenmenin temel ilkeleri; öğretmen ile öğrenci arasındaki ilişkinin bir ortaklık ilişkisi olduğunun altını çizer: Bu süreçte diyalog gereklidir ve patron yoktur. Hatta herkes, hem öğreten hem de öğrenen rolündedir. Özellikle öğretmenler, öğrencilerinden öğrenmeye hazır olmalı ve bunu bir kişilik özelliği haline getirmelidirler, (Trujillo, 1999 ve Şimşek 2002).

$\mathrm{Bu}$ problemli ve hiyerarşik ilişki sistemi, mimari tasarım eğitimi için de geçerlidir. 
Mimarlık eğitiminin temeli; mimari tasarım stüdyolarıdır. Mimari tasarım stüdyoları, gelenekselleşen usta-çırak ilişkisiyle yürütülür ve bu ilişki öğretici-öğrenici arasında yukarıda tanımlanan çelişkileri taşır. Stüdyolardaki otoriter ortam, öğrenicilerin yaratıcı düşünmelerinin önündeki en önemli engellerden biridir. Buradan hareketle bu çalışma, stüdyodaki alışılagelmiş ilişkileri değiştiren; öğrenici ile öğreticinin aynı düzlemde buluştuğu bir deneyimi önerir. Öğrenmekten öğrenmek amacıyla “öğretmen/öğrenci” rollerinin ortadan kaldırılmaya çalışıldığı bu uygulamada amaç; kanıksanan rollerin -tekrar eden alışkanlıklarının ve davranış kalıplarının sarsılması yolunda- öncelikle fark edilmesi, sorgulanması ve kalıcı olarak değiştirilmesidir.

Beklenen temel sonuçlar;

- Tekrar eden otoriter davranış kalıplarının yıkılması,

- Özgürlükçü, eleştirel, yaratıcı düşünmenin temel olduğu bir mimarlık eğitimi,

- Düşünen, sorgulayan, değiştiren ve dönüştüren bireyler yetiştirilmesi,

- $\quad$ Özgürlükçü eğitim yoluyla özgür ve demokratik bir toplum inşası konularında mimarlık alanındaki herkes için ortak bir tartışma zemini yaratılmasıdır.

Hem tasarım yöntemleri hem de mekan algısı açısından örtüşen bu iki alanın interdisipliner olarak tartışılması, mekanı, sinemanın tanımladığı sanal gerçeklikler üzerinden algılamaya alışkın bir kuşağa ait olan tasarım öğrenicilerine, mimari mekana yaklaşımları açısından önemli katkılar sağlamaktadır. Bu bağlamda, mekanın tasarlanması, temsiliyet araçları ile yeniden üretilmesi ve kullanıcıya sunulması konusunda sinema ile yakın ilişki kurulması, mimari mekanı öğrenicilere anlatırken öğreniciler tarafından bilindik ve tanınan araçları kullanmak yararcı bir yöntem olarak karşımıza çıkmaktadır.

Sine-Tasarım Atölyesi içeriği; sinema, mimarlık, etkileşim, mekan, tasarım beşlisinden hareketle, Karadeniz Teknik Üniversitesi, Mimarlık Bölümü, Lisans/Lisansüstü Programları kapsamındaki "Sinema ve Mimarlık" dersinin, Yıldız Teknik Üniversitesi bünyesinde gerçekleştirilen "Mimari Tasarım Eğitimi: Bütünleşme 2" konulu Ulusal Sempozyum kapsamında lisans düzeyindeki bir atölye çalışması aracılığıyla, farklı bir ölçekte ve farklı bir bakış açısıyla yeniden yorumlanmasını içermektedir.

"Sinema ve Mimarlık" dersinin üst amacı olan öğrenicilere sanatla yaşamı uzlaştıran öğretinin kazandırılması hedefi, atölye kapsamında "sinema ve mimarlıkta mekan" kurgusu özelinde ele alınmıştır.

Sinema ve mimarlıkta mekan konusunun tartıştırılmasına zemin oluşturmak üzere seçilen film Christopher Nolan'ın yazıp yönettiği 2010 yapımı "Inception (Başlangıç)" filmidir. Film kısaca; insanların rüya anlarında zihinlerine girerek iş hayatlarına ait sırları çalan bir hırsızın bu kez rüya anında bilinçaltına bir fikir yerleştirmesini konu alır. Bu işlem filmde, mimarlarca tasarlanan rüyaya ait olay kurgusu ve rüya mekanları içinde yapılır, (Bkz. Görsel1). Film bu yönüyle mekan tartışmalarına ek olarak sinema ve mimarlık ilişkisinin ikinci örneğini de verir: Filmin ana kahramanlarından ikisi mimardır ve filmin büyük çoğunluğunun geçtiği mekanlar film süresince o mimarlar tarafından tasarlanır ve tüm tasarım süreci paylaş1lır; film içindeki rüya mekanlarının önce çizimleri, sonra maketleri yapılır ve son olarak "gerçek" boyutlarıyla rüya anında karakterler tarafından yaşanırken izleyiciye gösterilir, (Bkz. Görsel 2). 


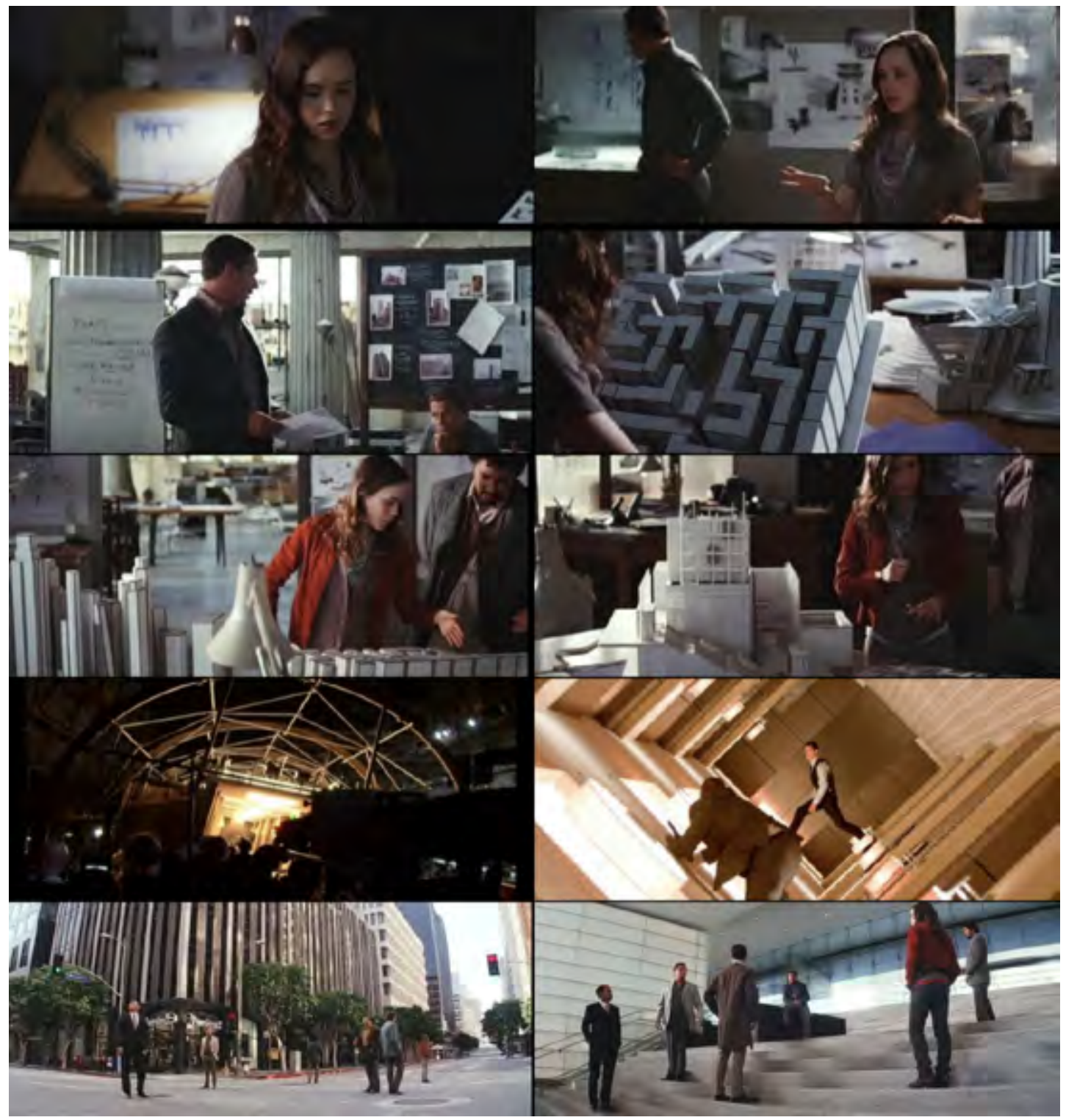

Görsel 1. Rüya Mekanları: Tasarım Aşaması

Filmin en önemli yanı ve tercih edilme sebebi ise sinemanın görsel imkanlarını gerçek dünyada oluşturulamayacak mekan paradoksları aracılığıyla yaratması; böylelikle mekanı, insan-mekan ilişkisine dair yeni sorgulama alanları açmak için kullanmasıdır. Filmde karşımıza çıkan çarpıtılmış, çoğaltılmış, ters çevrilmiş, algılayan kişiye, zamana ve harekete göre sınırları ve biçimi değişen, dönüşen mekanlardır. Doreen Massey'in sözleriyle; "filmin kuruluşu dünyaya ilişkin coğrafi imgelemimizi eleştirmeye ve yeniden düzenlemeye" teşvik eder, (Lury ve Massey, 1999). Bu dürtüyle öğrenicilerden beklenen; mekan kavramına getirdikleri öznel yorumları, mekan tasarımlarıyla sonuçlandırmaları olmuştur. 


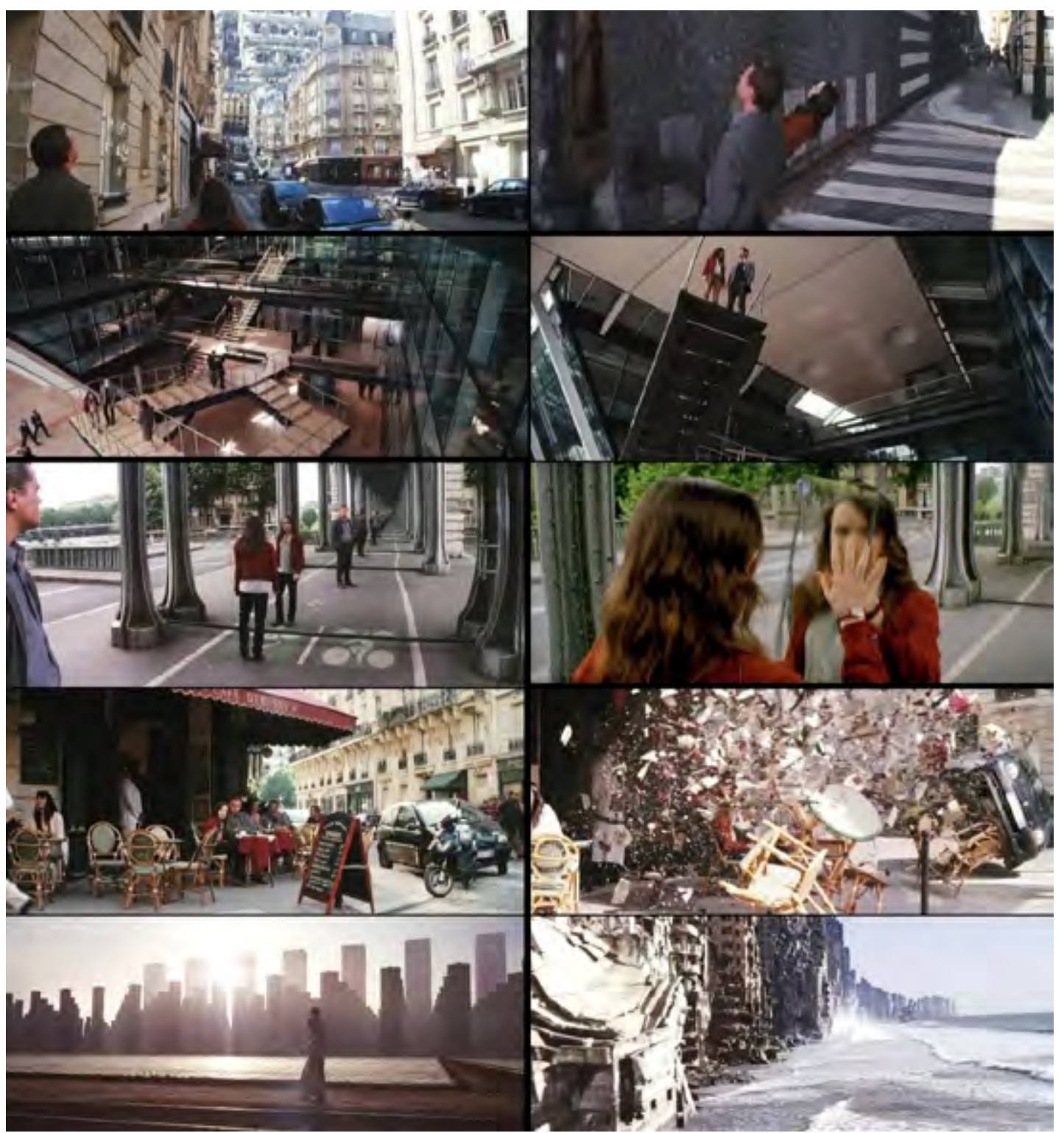

\section{Görsel 2. "Gerçek" Rüya Mekanları}

Atölye, sinemayı bir üst kavram olarak ele alırken izlenen filmin mekanını/mekanlarını mimari mekanın/mekanların birer temsili olarak kabul etmiştir. Bu bağlamda filmdeki mekan/mekanlar tartışmaya açılmış; filmin alışılagelmiş somut mekan algısını tersyüz eden yaklaşımı, amaçlandığı gibi, mekan kavramının kendisinin tartışılmasına sebep olmuştur. Ardından mekan kavramına getirilen eleştiriler, analizler ve yorumlar iki ve üç boyutlu mekan tasarımlarıyla sonuçlandırılmıştır.

Atölye süresince öğrenicilerin yaratıcılıklarını özgür bırakabilmeleri için gereken demokratik ortamı oluşturmak amacıyla kendi tasarımları ile ilgili karar haklarına sahip olmaları desteklenmiş ve tasarımlarına ait hiçbir mekan ya da ölçü kısıtlaması yapılmamış, çizim ve maket malzemeleri konusunda tercih kendilerine bırakılmıştır. Atölye çalışmasının tamamlanmasından sonra, geçirilen süreç, süreç boyunca yapılan tartışmalar, çalışmalar ve 
sonuç ürünlerin iki ve üç boyutlu görselleri, bir sergi ve panel sunumu ile "Mimari Tasarım Eğitimi: Bütünleşme 2" Ulusal Sempozyumu katılımcılarıylapaylaşılmıştır.

Tablo 5. Sine-Tasarım Atölye Kurgusu (Akış, Program, Şema ve İşleyiş)

\begin{tabular}{|c|c|}
\hline Atölye Adı: & Sine-Tasarım (Sinematik Mekan Tasarımı) Atölyesi \\
\hline Atölye Amacı: & Mimarlık ve ilgili disiplinlerin birlikteliği \\
\hline Konusu: & Sinema ve mimarlıkta mekan \\
\hline Kapsamı: & Bir filmi okuma, mekan, mekan analizi, mekanın yorumu ve yeniden tasarımı \\
\hline $\begin{array}{l}2 \text { Günlük } \\
\text { Atölye } \\
\text { Çalışması: }\end{array}$ & $\begin{array}{l}20 \text { Ekim } 2011 \text { Perşembe-Sabah Oturumu: Kuramsal } \\
\text { Çalışma: Bilgilenme-1: } \\
\text { - Sinema tarihi, } \\
\text { - Mimarlık tarihi, } \\
\text { - Sinema ve mimarlık etkileşimi, } \\
\text { - Sinema ve mimarlıkta mekan. }\end{array}$ \\
\hline Birinci Gün & $\begin{array}{l}20 \text { Ekim } 2011 \text { Perşembe-Öğleden Sonra Oturumu: Kuramsal ve Uygulamalı } \\
\text { Çalışma: Bilgilenme-2: } \\
\text { - Inception (Christopher Nolan, 2010) filminin izlenmesi. } \\
\text { - Filmin tartış1ması, } \\
\text { - Filmin mekan analizleri, } \\
\text { - Filmin mekanlarının yorumu. }\end{array}$ \\
\hline $\begin{array}{l}\text { Çalışma Yön- } \\
\text { temi: }\end{array}$ & $\begin{array}{l}\text { 21 Ekim } 2011 \text { Cuma-Sabah Oturumu: Uygulamalı Çalışma: } \\
\text { - Filmin seçilen mekanlarının } 2 \text { boyutlu (sözel, yazılı, çizgisel, grafik,...) } \\
\text { dışavurumu. }\end{array}$ \\
\hline $\begin{array}{l}2 \text { Günlük } \\
\text { Atölye } \\
\text { Çalışması: } \\
\text { İkinciGün }\end{array}$ & $\begin{array}{l}21 \text { Ekim } 2011 \text { Cuma- Öğleden Sonra Oturumu: Uygulamalı Çalışma: } \\
\text { - Filmin seçilen mekanlarının } 3 \text { boyutlu (modelleme,...) dışavurumu. } \\
\text { - Panel ve sergiye hazırlık. }\end{array}$ \\
\hline $\begin{array}{l}\text { Katılımcı Sayısı } \\
\text { ve Profili: }\end{array}$ & $\begin{array}{l}\text { İlk aşamada Yıldız Teknik Üniversitesi, Mimarlık Fakültesi, Mimarlık Bölümü } \\
\text { öğrenicileriyle yürütülmesi düşünülen atölyenin sosyal paylaşım siteleri aracılı̆̆ıla } \\
\text { da duyurulması sonucu atölye; } 14 \text { Yıldız Teknik Üniversitesi, Mimarlık Bölümü } \\
\text { öğrenicisinin yanı sıra, } 2 \text { Trakya Üniversitesi, Mimarlık Bölümü öğrenicisi ve } 2 \\
\text { Beykent Üniversitesi, Mimarlık Bölümü öğrenicisi katılımıla gerçekleştirilmiştir. }\end{array}$ \\
\hline $\begin{array}{l}\text { Gerekli } \\
\text { Ekipman: }\end{array}$ & $\begin{array}{l}\text { Bilgisayar, yansıtıcı, yazıcı, eskiz kağıtları, eskiz kalemleri, renkli kalemler, kartonlar, } \\
\text { mukavvalar, kesiciler, yapıştırıcılar, sergi panoları. }\end{array}$ \\
\hline
\end{tabular}


Tablo 5'de; Sine-Tasarım Atölye Kurgusu (Akış, Program, Şema ve İşleyiş)'nda görüldüğü üzere atölye, sinema ve mimarlık tanımlamaları, her iki disiplinin geçirmiş olduğu tarihsel süreç, etkileşimler ve mekan konularında bir bilgilenme ile başlamış; filmin tüm katılımcılar eşliğinde izlenmesinin ardından filmde öne çıan temalar, kavramlar ve mekanların tartışılmasıyla devam etmiştir. Bu aşamada, öğrenicilerin kendi seçtikleri kavramlar üzerinden düşüncelerini geliştirmelerine ve gruplar halinde fikir alışverişi yapmalarına zaman tanınmıştır. Bu sürecin sonunda öğreniciler, kendi seçtikleri kavramı en iyi ifade eden tanımı bir özgün tanım veya slogan aracılığıyla ifade etmişler; kavram üretimlerini fikre dönüştürmüşlerdir. Fikirlerin bir mekan aracılığı ile vücut bulması, öncelikle iki ve sonrasında hacim kazanan üç boyutlu mekan tasarımı ürünleri ile sonuçlandırılmıştır.

Örnek verecek olursak ilk grup, filme hakim olan gerçek ve rüya mekanları arasındaki yolculukların kesintiye uğradıkları anda, karakterlerin sıkışıp kaldıkları "araf" mekanlara odaklanmayı tercih etmiştir. Bu kavramı en iyi ifade eden varlık ve yokluk felsefesini, mekan ve zaman bağlamlarında tartışmaya açmışlardır. Bir sonraki aşamada bu fikri, iki ve üç boyutlu soyut anlatımlarla ifade etmişlerdir, (Bkz. Görsel 3).

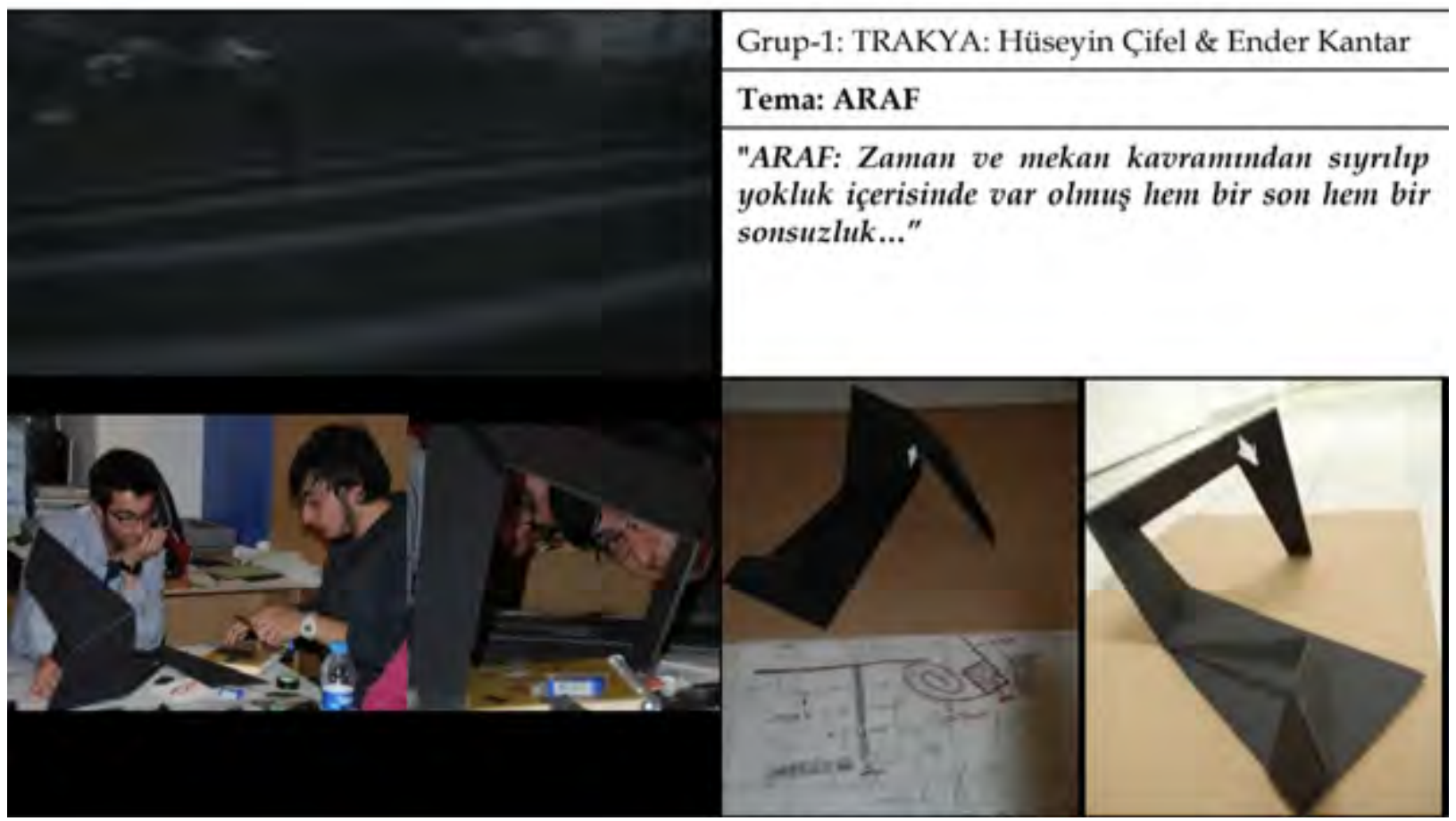

Görsel 3. Araf Kavramı, Tanımı, Mekanı

Filmde karakterler, filmin akışı içindeki kırılmalarla, süreklilik duygusundaki aşınma ve bozulmalarla deneyimledikleri mekanların, hafızalarındaki anıların devamlılı̆̆ ve gerçekliğiyle ilgili şüpheye düşerler. İkinci grup buradan hareketle zaman ve mekan içinde anların üst üste binmesine atıfla "katman" kavramını seçmiştir. Bu kavramı açıklarken de zaman parçalarının bitmesi ve yeniden başlaması arasındaki döngüselliğe vurgu yapılmıştır. Öğrenicinin bu düzlemde tasarladığı iki ve üç boyutlu çalışmalar aşağıda yer aldığı gibidir, (Bkz. Görsel 4). 


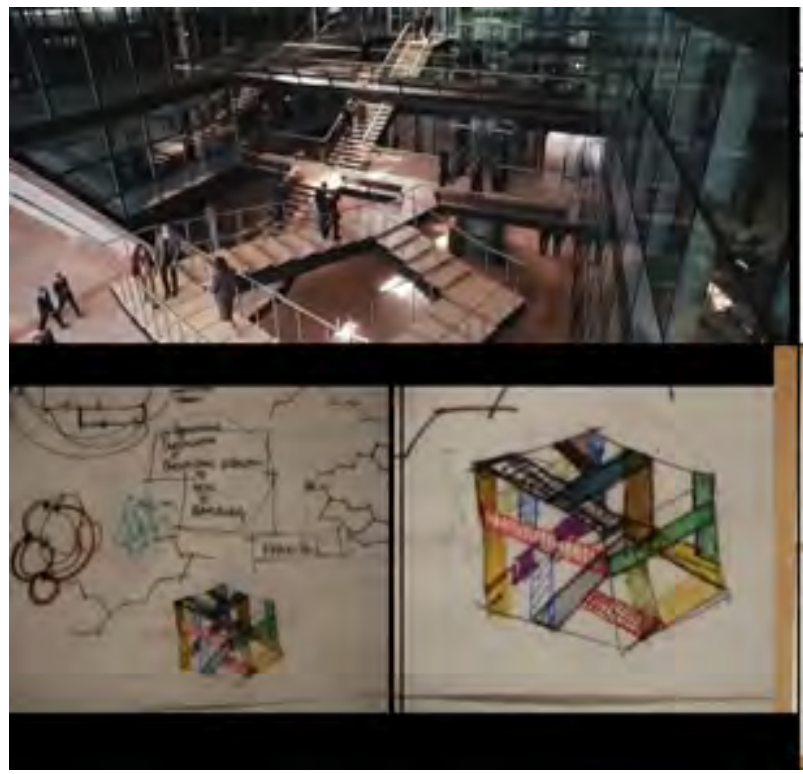

Grup-2: Oya Findik

Kavram: KATMAN

"KATMAN: Zaman parçalayan, parçaladıkça çoğaltan, bitebilen ancak bittiği noktada başlangıca uzanan, başka bir katmanla birleşerek döngüselliğe giden bir haldir..."

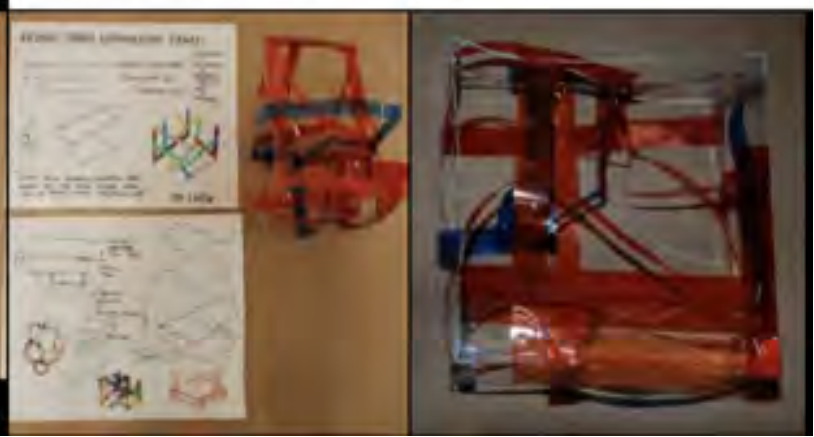

Görsel 4. Katman Kavramı, Tanımı, Mekanı

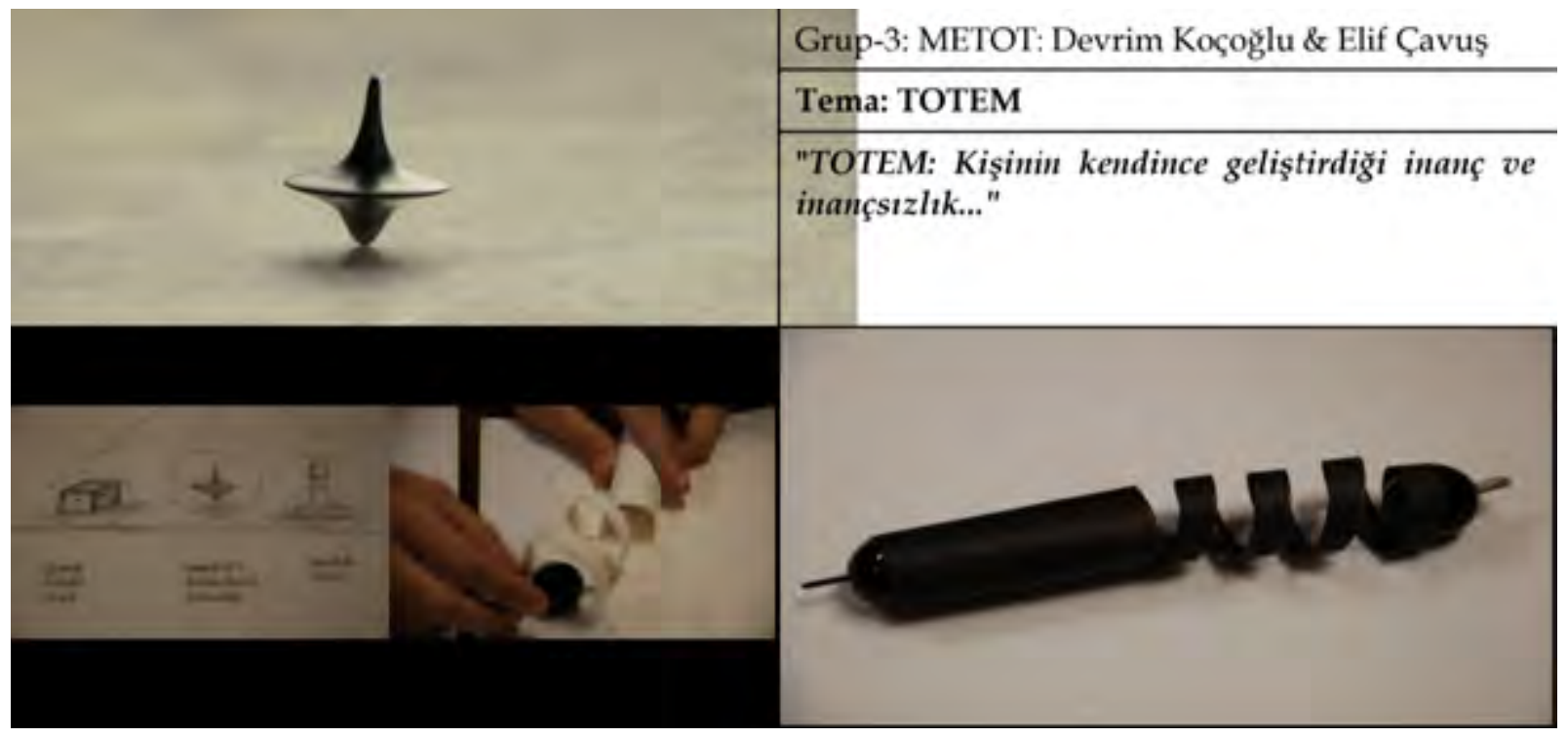

Görsel 5. Totem Kavramı, Tanımı, Mekanı

Filmdeki karakterlerin gerçek ve rüya mekanları arasında yolculuklarında gerçeklik duyguları ortadan kalktığında başvurabilecekleri tek kaynak kendi seçtikleri objelerdir. Bu objeler karakterler için bir can simidi kadar hayati önemdedir. Sıradan bir objeye yüklenen bu kadar büyük bir anlam, üçüncü grubun odaklanmayı seçtikleri konudur. Bu grup, ister bir obje olsun, ister bir davranış kalıbı, insanların inanmayı seçtikleri "totem"leri ve aslında bu inancın altında yatan inançsızlı̆̆ı vurgulamıştır, (Bkz. Görsel 5). 
"Yansımalar", sinema tarihi boyunca birçok yönetmen tarafından önemsenmiş, pek çok yönetmen filmlerinde yansımalar kullanmayı tercih etmiştir. Dördüncü grup da bu filmde yansımanın taşıdığı anlamlar üzerinden mekanları rüya-gerçek ikililiği eşliğinde tartışmıştır, (Bkz. Görsel 6).

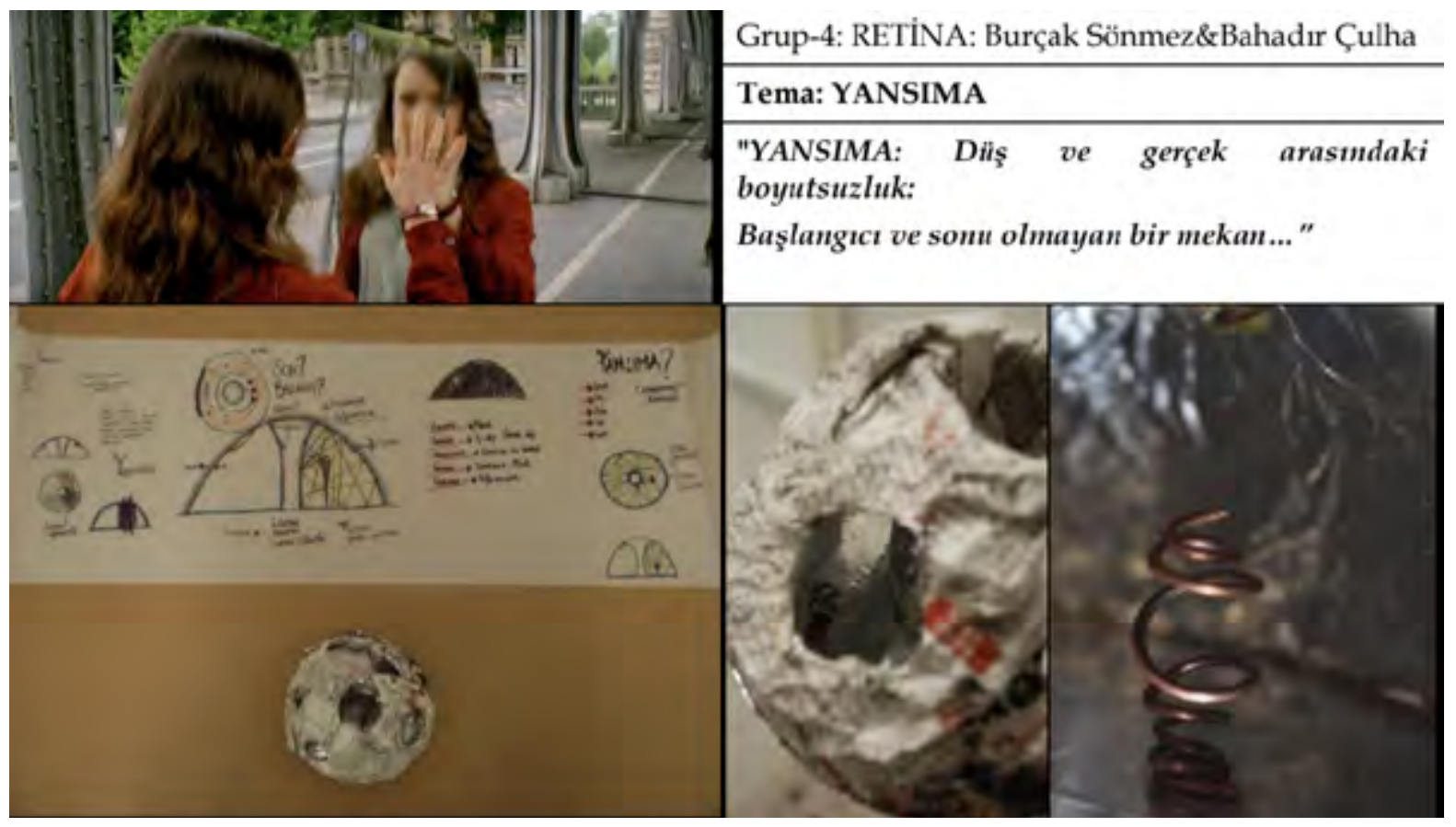

\section{Görsel 6. Yansıma Kavramı, Tanımı, Mekanı}

Beşinci ve altıncı gruplar birbirlerinden bağımsız olarak, filmdeki birden çok sahneyi açıklamak için "paradoks" kavramının kullanılabileceğini ileri sürmüşlerdir. Filmdeki hareketin ve sürekliliğin hangi koşulla olursa olsun sonuçta hiçbir yere varmayacağını anlatmak için hem mekanlar arasındaki sıçramalara hem de zamandaki kırılmalara dikkat çekerek, paradoks kavramını Escher'vari illüzyonlar olarak açıklamışlardır, (Bkz. Görsel 7 ve 8). 


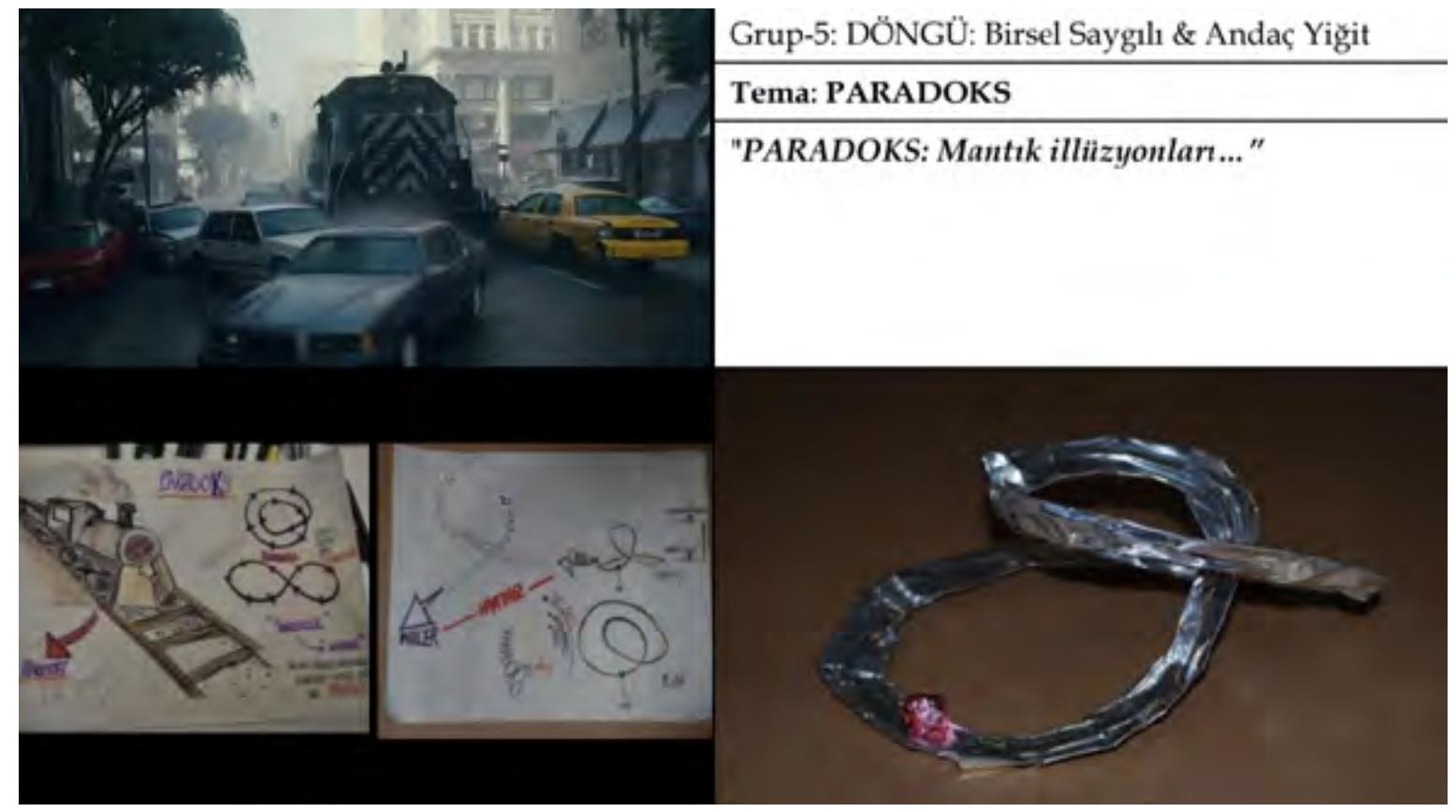

Görsel 7. Paradoks Kavramı, Tanımı,Mekanı-I

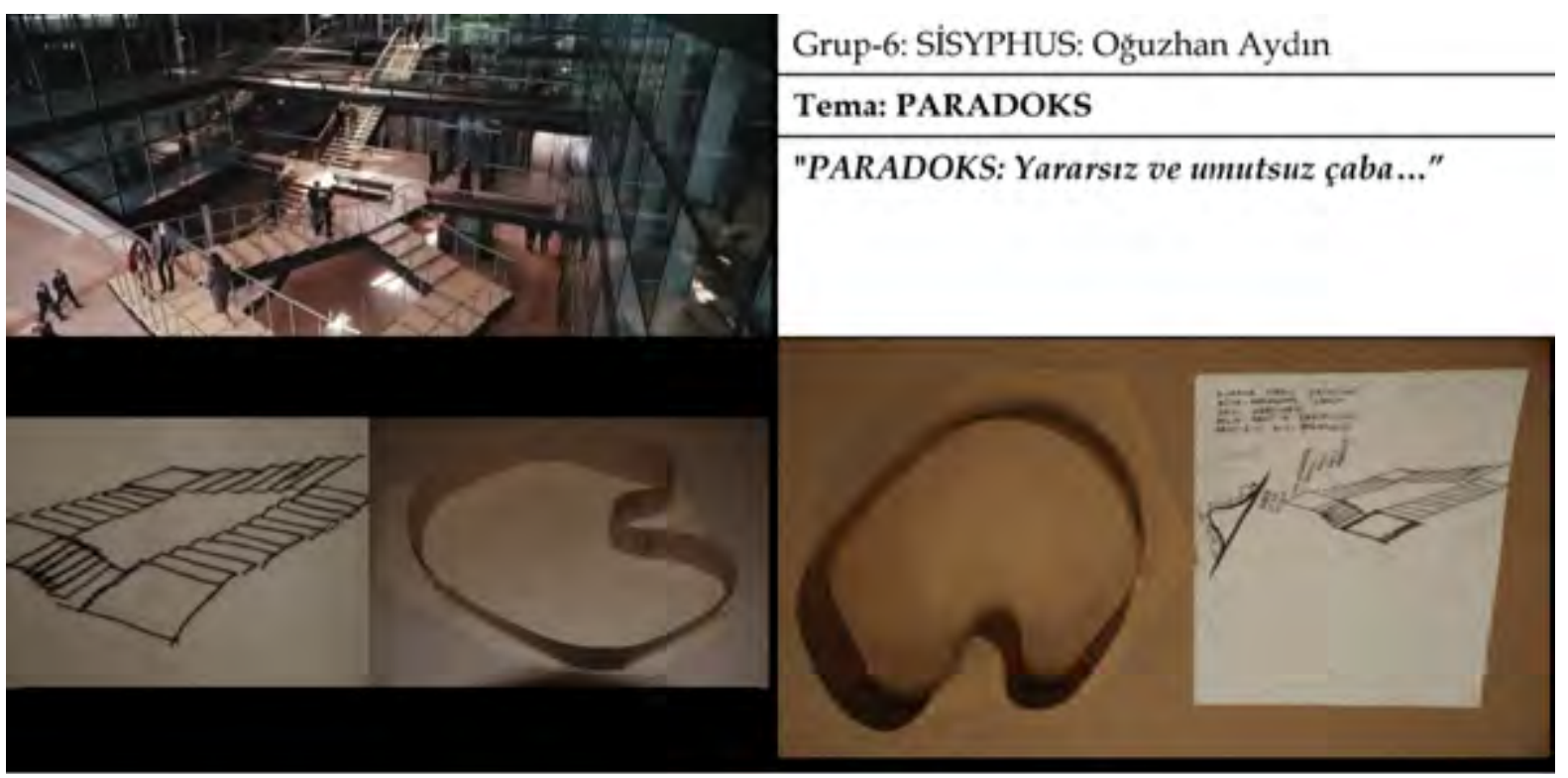

\section{Görsel 8. Paradoks Kavramı, Tanımı,Mekanı-II}

Filmin görsel açıdan zengin sinematik mekanları arasında, karakterlerin bitmek bilmeyen yolculukları, filmin seyrini keyifli kılan en önemli unsurdur. Bu hareketin mekanla ilişkisi Grup 7 ve Grup 8 tarafından filmin en temel özelliği olarak değerlendirilmiştir. Böylelikle "hareket ve mekan" ikilisini tartışan ekipler aşağıdaki sözel ve görsel araçlarla düşüncelerini ifade etmişlerdir, (Bkz. Görsel 9 ve 10). 


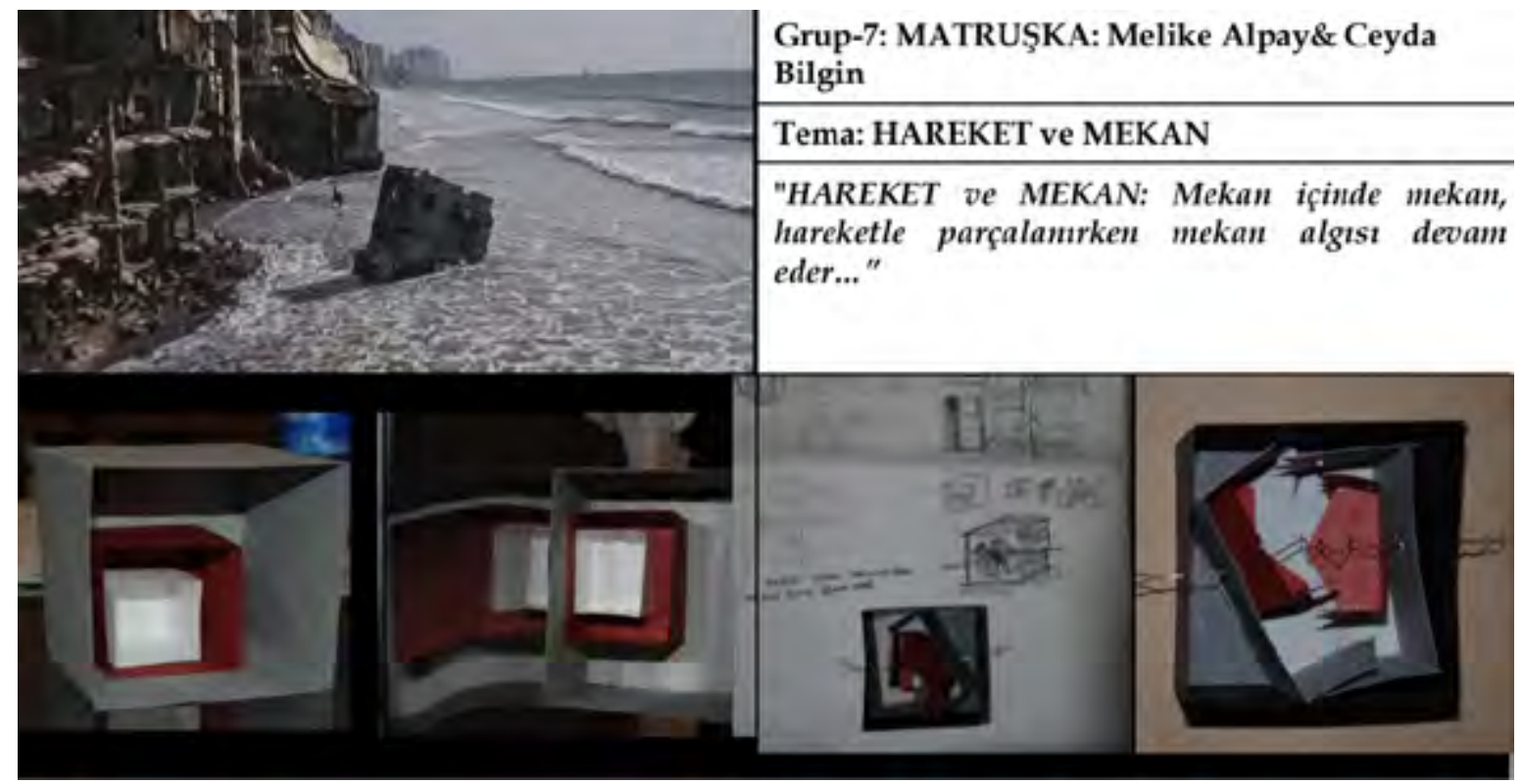

Görsel 9. Hareket ve Mekan Kavramı, Tanımı, Mekanı-I

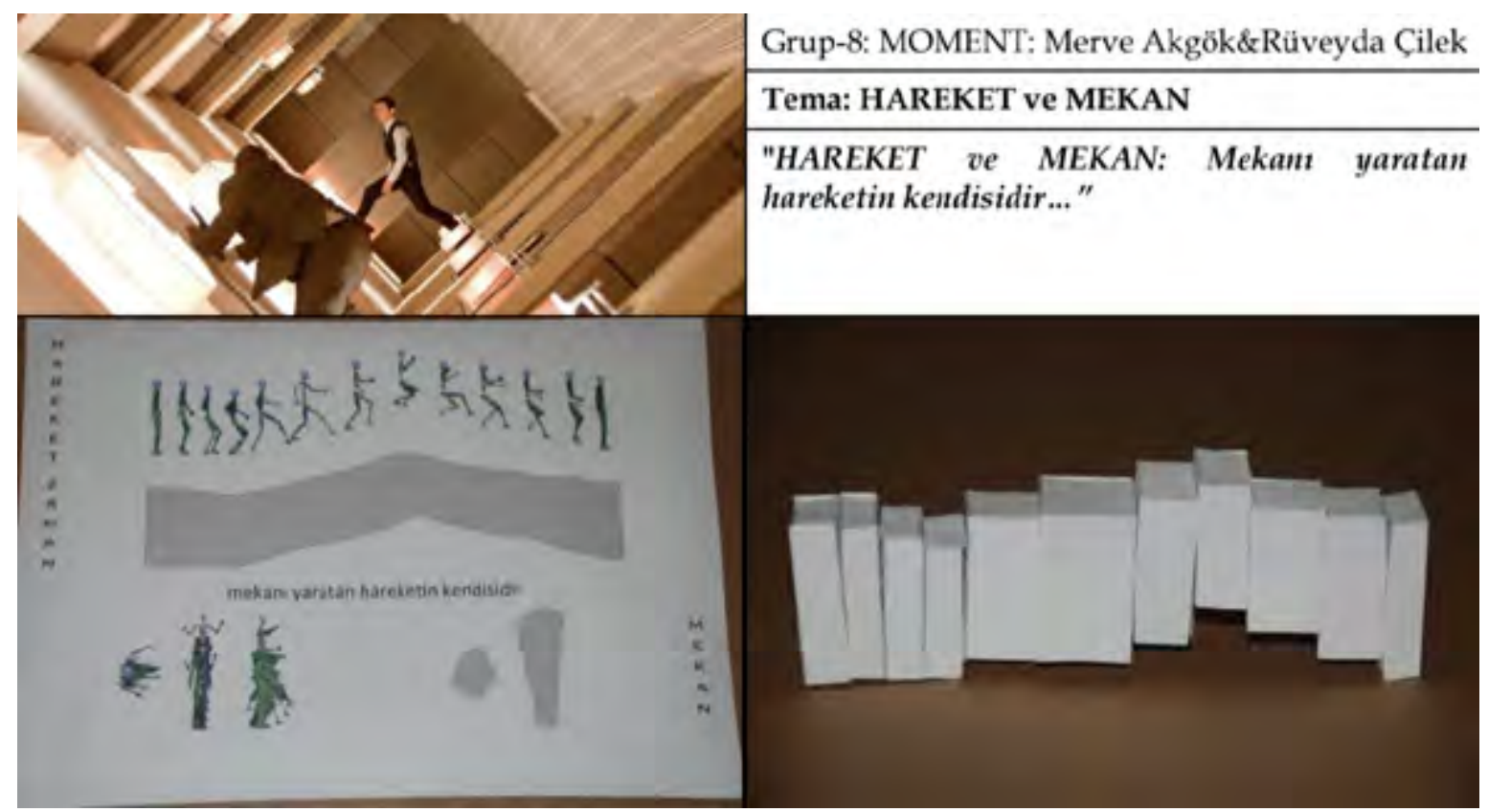

Görsel 10. Hareket ve Mekan Kavramı, Tanımı, Mekanı-II

Öğreniciler tarafından seçilen son tema yine bir kavram çiftidir: "Zaman ve mekan" konusunda odaklanmayı seçen iki grup, bu iki kavramın birbirleriyle olan ilişkilerini tartışmaya açmayı hedeflemiştir. Grup 9 için bu iki kavram birbiri içinde erirken Grup 10'a göre mekan zaman için bir gösterge niteliği taşımaktadır, algılayan için zamanı var etmektedir, 
(Bkz. Görsel 11 ve 12).

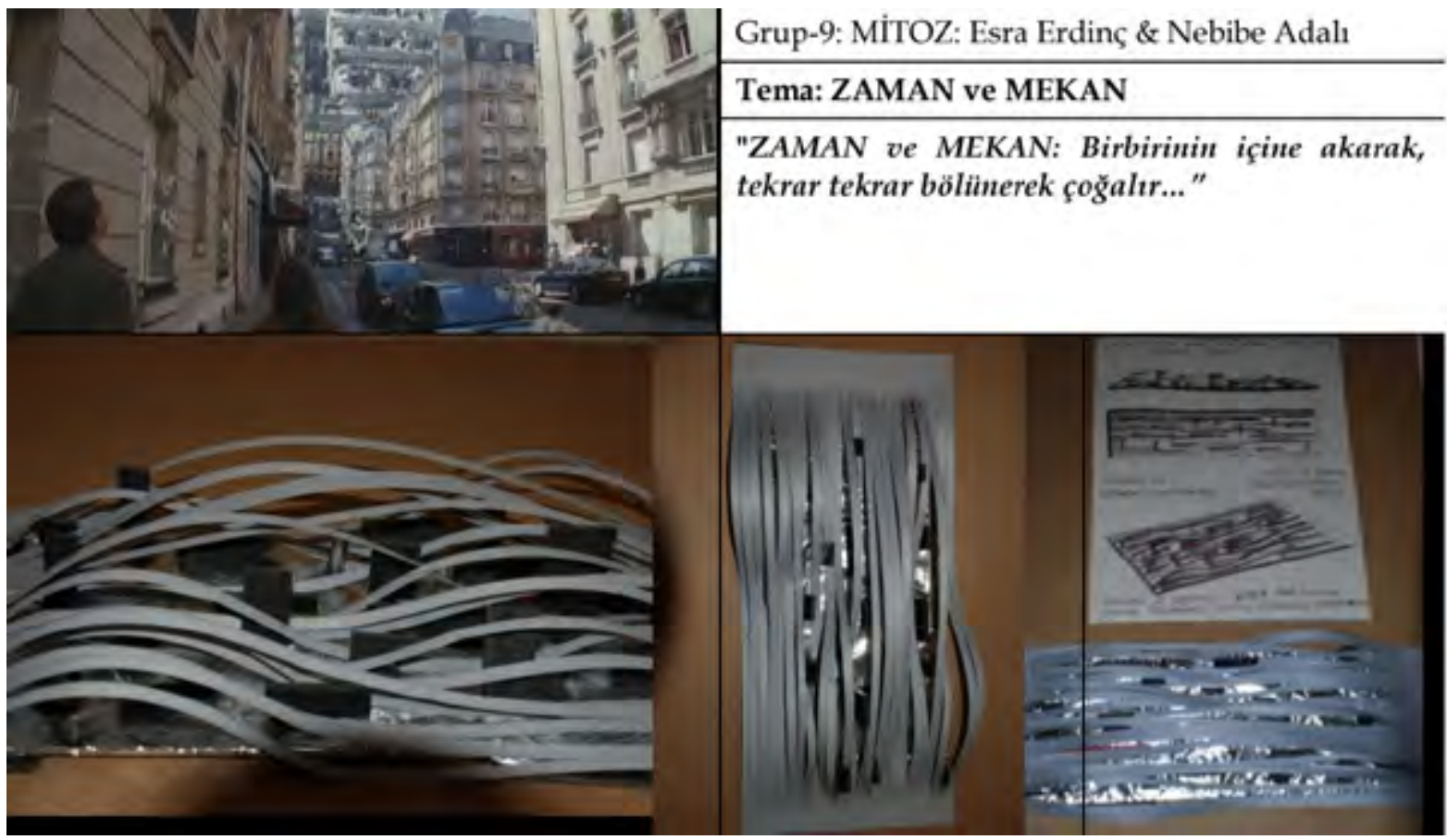

Görsel 11. Zaman ve Mekan Kavramı, Tanımı, Mekanı-I

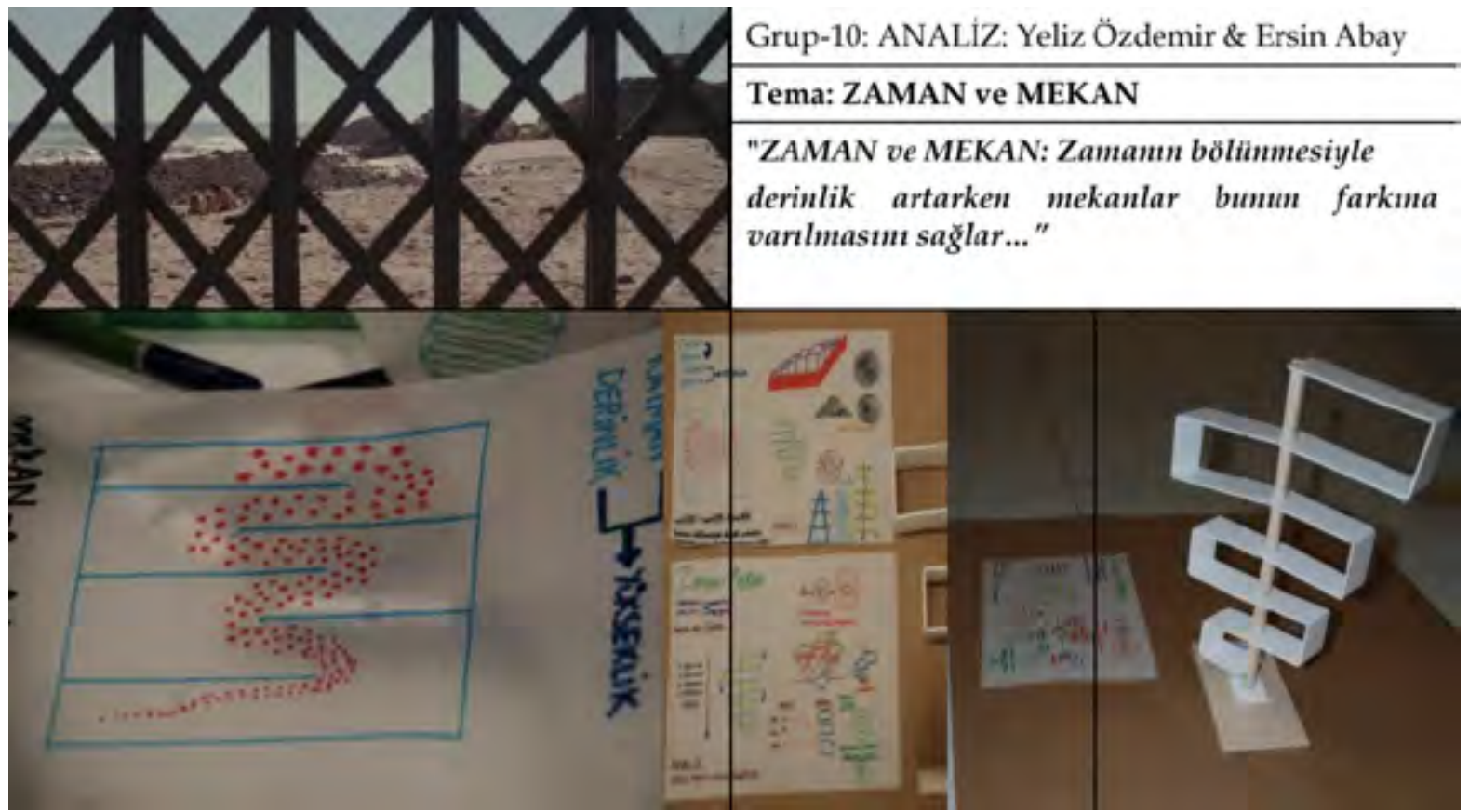

Görsel 12. Zaman ve Mekan Kavramı, Tanımı, Mekanı-II

Atölye sonucunda, öğrenicilerin ileri sürdüğ̈̈ kavramların, sloganların, kendilerini ifade etme biçimlerinin ve tasarladıkları ürünlerin başarılı olduğu görülmüştür. Buna sebep 
olan ortamı hazırlayan şartlardan bazılarının, atölyenin üniversite programları dahilinde uygulanan eğitim sisteminden aşağıdaki şekillerde farklılaşması olduğu düşünülmüştür:

- Onların yerine tercih yapan, bu dersi eğitim programında zorunlu veya seçmeli dersler arasına koyan başka birinin bulunmaması,

- $\quad$ Öğrenicilerin atölyeye gönüllü katılımı,

- $\quad$ Öğrenicilerin akademik bir değerlendirmeye alınmayacaklarını bilmeleri,

- Öğgrenicilerin atölye sonucunda harfli bir not almayacak olmalarl, bu şekilde değerlendirilmelerinin öğrenicilerin birbirleriyle kıyaslanmasını beraberinde getirmesi, deneyimlerinin A-F aralığında derecelendirilmeyecek olması,

- $\quad$ Aynı şekilde transkriptlerinde geçti/kaldı, başarılı/başarısız gibi herhangi bir kayıt olmayacağını bilmeleri ve yapacakları tüm katkıların herhangi bir değerlendirmeden geçmeden kabul görecek olması,

- $\quad$ Tasarım süreçlerinde talep etmedikleri sürece herhangi bir yönlendirme veya müdahalede bulunulmamış olması,

- Üniversitelerdeki yaygın mimari tasarım stüdyolarının aksine sonuç ürün için herhangi bir işlev dayatması ve şartname bulunmaması,

- $\quad$ Süreç içinde ve sonunda kullanılacak iki veya üç boyutlu araçlar ile sunum dilinin serbest birakılmış olması,

- $\quad$ Ders için materyalin bir sinema filmi olması, öğrenicilerce diğer geleneksel ders materyallerinden daha kolay kavranabilen ve görsel bir araç olması,

- $\quad$ Atölye ortamının mimarlık ve diğer disiplinler arası ilişki ve etkileşimi destekliyor olmas1,

- $\quad$ Sinema ve mimarlık ilişkisine duyulan merak,... gibi etkenlerin, atölye sonunda katılıma öğrenicilerin geri dönütleriyle de desteklendiği tespit edilmiştir. Bu bağlamda, atölye süreci ve sonuç ürünlerinin atölye yürütücüleri kadar öğrenicileri de memnun ettiği düşünülmektedir.

\section{Sonuçlar}

"Sinema bir dil, bir biçimdir (sözce). Biçimin ise bir üretilme süreci vardır dolayısıylasinema -her film- özel bir söylem biçimidir (sözceleme). Söz konusu süreçte anlam üretiminin çoğuzaman belli bir bağlamda, ikinci elden gereçlerin yeniden kullanılmasıyla gerçekleştiği yadsınamaz bir gerçekliktir."

Kubilay Aktulum, 2018 
Çalışma kapsamında eğitim faaliyetinin teorik içeriği kadar öğrenicilerin nasıl bir deneyim yaşadıkları da önemsenmiştir. Atölyenin başlangıcından sonuna kadarki süreç boyunca öğrenicilerin yaşaması planlanan öğrenme deneyimi Tablo 6'de şematik olarak anlatılmıştır:

Tablo 6. Sine-Tasarım Atölye Değerlendirmesi

(Başlangıç/Giriş: Sorular, Süreç/Gelişme: Kavramalar, Bitiş/Sonuç: Kazanımlar)

\begin{tabular}{|c|c|}
\hline \multicolumn{2}{|c|}{ Başlangıç/Giriş: Sorular } \\
\hline Merak & $\begin{array}{l}\text { - Ne yapacağım? } \\
\text { - Neden yapacağım? } \\
\text { - Nasıl yapacağım? } \\
\text { - Nasil ifade edeceğim? }\end{array}$ \\
\hline $\begin{array}{l}\text { Sorma- } \\
\text { Sorgulama }\end{array}$ & $\begin{array}{l}\text { - Nasıl bir deneyim yaşadım? } \\
\text { - Bu deneyim hakkında ne düşündüm? } \\
\text { - Bu deneyim hakkında neden düşündüm? } \\
\text { - Bu deneyim hakkında nasıl düşündüm? } \\
\text { - Bu deneyim hakkında neler hissediyorum? } \\
\text { - Yargılarken temelde hangi ölçütleri, değerleri göz önüne aldım? } \\
\text { - Neden bazı şeylerden hoşlanıyor, bazılarından hoşlanmıyorum? } \\
\text { - Durumu daha iyiye götürebilmek için ne yapabilirim? }\end{array}$ \\
\hline \multicolumn{2}{|c|}{ Süreç/Gelişme: Kavramalar } \\
\hline $\begin{array}{l}\text { Anlama Tanıma } \\
\text { Kavrama } \\
\text { İliş̧kiler kurma } \\
\text { Yorumlama } \\
\text { Analiz etme } \\
\text { Senteze ulaşma }\end{array}$ & $\begin{array}{l}\text { - Sinema, } \\
\text { - Mimarlık, } \\
\text { - Mekan (kavramını farklı disiplinler aracılığı ile anlama), } \\
\text { - Tanıma, } \\
\text { - Kavrama, } \\
\text { - Yeniden yorumlama. }\end{array}$ \\
\hline \multicolumn{2}{|c|}{ Bitiş/Sonuç: Kazanımlar } \\
\hline $\begin{array}{l}\text { İfade etme } \\
\text { Sözel } \\
\text { Çizim diliyle (2B) } \\
\text { Model diliyle (3B) }\end{array}$ & $\begin{array}{l}\text { - Soyut düşünme, } \\
\text { - Kavramsal düşünme, } \\
\text { - Varolanla olmayan arasında ilgi kurma, } \\
\text { - Düşünüleni bir özle ifade etme, } \\
\text { - Düşünüleni özsel biçimlerle ifade etme, } \\
\text { - El, yürek, beyin birlikteliğini gerçekleştirme, } \\
\text { - Sezgi, duygu, imgelem, duyu organları birlikteliğini gerçekleştirme. } \\
\text { - Özgür bir ortamda mekan tasarlama,üretme, } \\
\text { - Özgün ve yaratıcı fikirler ortaya koyma, } \\
\text { - Özgür, özgün ve yaratıcı fikirleri mekana dönüştürebilme. } \\
\text { - Kendini tanıma, } \\
\text { - Kendini dönüştürme, } \\
\text { - Kendini yeniden yaratma, } \\
\text { - Kendini aşma, } \\
\text { - Kendini kanitlama. } \\
\text { - Sanat etkinliği ile benliği kişiliğge dönüştürme, } \\
\text { - Eğitim etkinliği ile değişim yaşama. } \\
\text { - İnteraktif öğrenme, } \\
\text { - Bir gruba ait olma/aidiyet yaşama, } \\
\text { - Grup çalışması deneyimi kazanma, } \\
\text { - Yeni birliktelikler, ilişkiler, dostluklar edinme. }\end{array}$ \\
\hline
\end{tabular}


Yapılan çalışma sonucunda, mimari tasarım sürecinde sinema sanatından görsel ve düşünsel yönden yararlanılabileceği olgusu doğrulanmaktadır. Bu iki yön, çalışmanın ana kurgusu olan sinema ve mimarlığın yöntemsel, terminolojik, deneysel ve eğitsel gibi görsel tüm etkileşim özelliklerinin tasarım süresince öğrenicilere katkı sağladığını ortaya koymaktadır.

Görsel bilgilenme ile öğreniciler, film kurgusu içinde doğrudan yer alan insan, zaman ve mekanlara ait okumalar yapabilir; eleştirel öz yorumlar getirebilirler. Tasarım sürecinde yeri olan bu bilgilenme-eleştirme-yorumlama adımları, filmin görsel varlığıla doğrudan ilişkilendirilebilir. Tasarım sürecinde, sinema sanatından düşünsel olarak yararlanma adımında ise öğreniciler, filmin kurgusu, ana teması, verilmek istenilen mesaj/mesajlar, kodlar, simgeler, mecazlar/metaforlar gibi soyut düşüncelerden hareket ederek tasarımlarına bir başlangıç noktası oluşturabilirler. Bu adım, film okurunun filmle kurduğu dolaylı bir ilişkidir ki tasarım süreci içindeki "yaratıcılık" olgusunu geliştirir ve destekler niteliktedir.

Böylelikle, öğreniciler, yaratıcı düşünme becerilerini harekete geçirmek üzere, genellikle fiziksel şartlarla sınırlı olarak algılanan mekanın limitsiz bir görsel temsili olan filmi, tasarım sürecine katkı sağlamak amacıyla kullanabilirler. Buradan hareketle, her iki yaklaşımın mimarlığın bilgi alanını ve mimari tasarım sürecini beslediği söylenebilir. Film mekanlarından mimari mekanı sorgulama aracı olarak yararlanılması, mekan araştırmaları ve mekan tasarımları için geniş bir kaynak ve çalışma alanı olarak görülebilir.

Plutarkhos'a göre; "zihin, doldurulacak bir çanak değil, tutuşturulacak bir ateştir" (Aktaran Boelen, Botha ve Sacchetti, 2018). Bu anlamda, burada anlatılan atölyeden ve benzerlerinden edinilen deneyimlerin öğrenicilerin kavramlar aracilığıyla soyut düşünme becerilerini geliştireceği, öğrenicilerin zihninde kıvılcımlara sebep olacağı düşünülmektedir. Benzer deneylerin yapılması ve paylaşılmasının bütün bir tasarım eğitimi geleneğini dönüştürmede katkı sağlayacağı umulmaktadır.

Tüm bunların bir sonucu olarak, öğrenicilerin mekana dair filmin önerdiği yeni düşünme biçimlerini anlayarak ve filmin onlara yaşattığı deneyimi yorumlayarak tasarım süreçlerini dönüştürdükleri bir gerçektir.

Bir filmi öğreniciler aracılığıyla yeniden okumanın eğitim ve sanat ilişkisinde -her iki kavramın ortak özelliği olan- bireyin kendini ve mekanı tanıma, dönüştürme, yeniden yaratma ve yaşamda bir değişim meydana getirme çabalarının "mimarlık eğitimi" olgusuna farklı bakış açıları getireceğine inanılmaktadır.

\section{Kaynaklar}

Aktulum, Kubilay. (2018). Sinema ve Metinlerarasıllk: Filmlerarası Etkileşimler ve Aktarımlar. Konya: Çizgi Kitabevi Yayınları.

Baysan Serim, Iş1l. (2014). Mimarlık ve Sinema İttifakının Soykütüğü Üzerine. Betonart.

Beşışık, Gökçe. (2013). Sinema ve Mimarlıkta Mekan Kurgusu ve Kavrayışı. (Yayınlanmamış yüksek lisans tezi). Dokuz Eylül Üniversitesi, Fen Bilimleri Enstitüsü. İzmir. 
Boelen, Jan, Botha, Nadine ve Sacchetti, Vera. (2018). Okullar Okulu: Bienalden Şüphelenmek, Tasarımdan Şüphelenmek. Kolektif, Öğrenme Biçimi Olarak Tasarım: Okullar Okulu Okumaları. İstanbul: İstanbul Kültür Sanat Vakfı.

Bozkurt, Nejat. (1995). Sanat ve Estetik Kuramları. İstanbul: Sarmal Yayınevi.

Buñuel, Luis. (1996). Introduction. Dietrich Neumann (Ed.), Film Architecture: Set Designs from Metropolis to Blade Runner. Munich: Prestel-Verlag.

Doğanay, Ahmet. (2002). Yaratıcı Öğrenme. Ali Şimşek (Ed.), Sınıfta Demokrasi. Üçüncü Basım. Ankara: Eğitim Sen Eğitim ve Bilim Emekçileri Sendikası.

Dostoğlu, Sibel. (1981). Tarih, Mimarlık Tarihi ve Bazı Kavramlar. Mimarlık, 81/3. Ertürk, Selahattin. (1997). Eğitimde Program Geliştirme. Ankara: Meteksan.

Fisher, Robert. (1995). Teaching children to think. London: Stanley Tornes.

Frampton, Daniel. (2013). Filmozofi: Sinemayı Yepyeni Bir Tarzda Anlamak İçin Manifesto. Çeviren: Cem Soydemir. İstanbul: Metis Yayınları.

Freire, Paulo. (1995). Ezilenlerin Pedagojisi. Çevirenler: Dilek Hatlatoğlu ve Erol Özbek. İkinci Basım. İstanbul: Ayrıntı Yayınları.

İnce, Tahsin, Erbil. (2007). Mimarlık Sinema İlişkisinin Sokak Mekanı Üzerinden İncelenmesi. (Yayınlanmamış yüksek lisans tezi). Gazi Üniversitesi, Fen Bilimleri Enstitüsü. Ankara.

Kreber, Carolin. (Ed.) (2009). The University and its Disciplines: Teaching and Learning Within and Beyond Disciplinary Boundaries. New York, N.Y. : Routledge.

Lefebvre, Henri. (2014). Mekanın Üretimi. Çeviren: Işık Ergüden. İstanbul: Sel Yayıncıllı. Lury, Karen ve Massey, Doreen. (1999). Making Connections, Screen 40/3.

Mimari Tasarım Eğitimi: Bütünleşme. (2011).http://www.mteus.yildiz.edu.tr/index. htm Son erişim tarihi: 28.12.2018.

YÖK (Yükseköğretim Kurumu) Lisans Atlası, (2019). Mimarlık Programı Bulunan Tüm Üniversiteler. http://yokatlas.yok.gov.tr/lisans-bolum.php?b=10155 Son erişim tarihi: 20.03.2019.

Pallasmaa, Juhani. (2001). The Architecture of Image: Existential Space in Cinema, Helsinki: Rakennustieto.

Pallasmaa, Juhani. (2008). Sinema ve Mimarlık. Çeviren: Ilgın Külekçi. Derya Karadağ (Ed.) http://v3.arkitera.com/g143-sinema-ve-mimarlik.html?year=\&aID=2621 Son erişim tarihi: 28.12.2018.

Şimşek, Ali. (2002). Özgürlükçü Öğrenme. Ali Şimşek (Ed.), Sınıfta Demokrasi. Üçüncü Basım. Ankara: Eğitim Sen Eğitim ve Bilim Emekçileri Sendikası.

Soygeniş, Sema. (2006). Mimarlık Düşünmek Düşlemek. İstanbul: Yem Yayınları. Tanyeli, Uğur. (2001). Sinema ve Mimarlık: Temsiliyet Nesnenin Temsili Sanatın 
Sanallıkla İfadesi. Arredamento Mimarlık. 11/66.

Thomas, Emma ve Nolan, Christopher (Yapımc1), Nolan, Christopher (Yönetmen). (2010). Inception [Sinema Filmi]. ABD: Warner Bros. Pictures.

Trujillo, Frank. (1999). Öğrencilerime Mektup. Çeviren: Ali Şimşek. Eğitim ve Yaşam, 15. Yorgancıŏ̆lu, Derya. (2011). Mimari Tasarım Eğitiminde Disiplinler Arası İşbirliğinin Önemi:

Tarihsel Arka Planın Yeniden İnşası. Mimari Tasarım Eğitimi: Bütünleşme 2 Ulusal Sempozyumu. İstanbul: Yıldız Teknik Üniversitesi. https:/ / www.researchgate.net/profile/

Derya_Yorgancioglu/publication/275463767_MIMARI_TASARIM_EGITIMINDE_ DISIPLINLER_ARASI_ISBIRLIGININ_ONEMI_TARIHSEL_ARKA_ PLANIN_YENIDEN_ INSASI/links/553d1a520cf245bdd76ab677/MIMARI-TASARIM- $\quad$ EGITIMINDEDISIPLINLER-ARASI-ISBIRLIGININ-OeNEMI-TARIHSEL-ARKA-PLANIN-YENIDENINSASI.pdf Son erişim tarihi: 22.12.2018.

Zevi, Bruno, Barry, Joseph A. ve Gendel, Milton. (1957). Architecture as Space: How to Look At Architecture. New York: Horizon Press. 